No $2006-24$

December

Changing Patterns of Domestic and Cross-Border Fiscal Policy Multipliers in Europe and the US

Agnès Bénassy-Quéré Jacopo Cimadomo 


\section{Changing Patterns of Domestic and Cross-Border Fiscal Policy Multipliers in Europe and the US}

Agnès Bénassy-Quéré Jacopo Cimadomo

No $2006-24$

December 


\section{Contents}

1 Introduction $\quad 8$

2 Methodology 11

2.1 A "factor-augmented" VAR for fiscal policy analysis . . . . . . . . . . . 11

2.2 Single country model: shocks identification . . . . . . . . . . . . . 15

2.3 Two-country model: shocks identification . . . . . . . . . . . . . . 17

3 The Data $\quad 18$

4 Domestic effects of fiscal shocks 19

4.1 Full sample estimation . . . . . . . . . . . . . . . . . . . . . . 19

4.2 Evolving domestic multipliers: recursive analysis . . . . . . . . . . . . . 20

4.3 Recursive GDP variance decomposition . . . . . . . . . . . . . . . 21

5 Cross-border effects of German fiscal shocks 22

5.1 Full sample estimation . . . . . . . . . . . . . . . . . . . . 22

5.2 Evolving cross-border multipliers: recursive analysis . . . . . . . . . 22

5.3 Recursive variance decomposition: foreign GDP . . . . . . . . . . . . . 23

6 Robustness checks $\quad 23$

7 Comparing fiscal VAR and FAVAR models $\quad 24$

8 Conclusions $\quad 24$ 


\section{Changing Patterns of Domestic and Cross-Border fiscal Policy MULTIPLIERS IN EUROPE AND THE US}

\section{SUMMARY}

The way fiscal policy impacts on domestic and foreign economies depends on several factors. In particular, the presence of excess capacity, accommodating monetary policy, distortionary taxation and liquidity constrained consumers, plays a prominent role in affecting how fiscal policies feed into the economic activity in the home country. The impact on foreign output depends crucially on the importance of trade links, on real exchange rates and, in a monetary union, on the sensitiveness of private investment and consumption to the common interest rate. The last thirty years have witnessed frequent changes in the economic environment. For instance, in most OECD countries, the monetary policy stance became less accommodating in the 1980s compared to the 1970s, and more accommodating again in the late 1990s and early 2000s. Moreover, financial markets have been heavily deregulated. Hence, fiscal policy might have lost (or gained) power as a stimulating tool in the hands of policymakers.

This study attempts to shed more light on the time evolution of domestic and cross-border tax and spending multipliers. We analyze the domestic impact of fiscal shocks in Germany, the UK and the US and cross-border fiscal spillovers from Germany to the seven largest European economies. By estimating small-scale vector autoregression models, "augmented" by factors representing developments in the world economy, it is found that over the period 1971 to 2004 tax shocks have generally been more effective in spurring domestic output than government spending shocks. This might be due to the fact that tax policies may rise potential growth in the long run, especially when distortionary taxes are removed thus increasing economic efficiency and competitiveness. Government spending shocks, on the contrary, are more likely to crowd out the private sector. When the estimation is performed recursively over samples of seventeen years of data, it emerges that GDP multipliers have dropped drastically from early 1990s on, especially in Germany (tax shocks) and in the US (both tax and government spending shocks). Moreover, the conduct of fiscal policy seems to have become less erratic, as documented by a lower variance of fiscal shocks over time, and this might contribute to explain why business cycles have shown less volatility in the countries under examination. Expansionary fiscal policies in Germany do not generally have beggar-thy-neighbor effects on other European countries. In particular, when shorter subsamples are analyzed, our results suggest that tax multipliers have been positive but vanishing for neighboring countries (France, Italy, the Netherlands, Belgium and Austria), weak and mostly not significant for more remote ones (the UK and Spain). Cross-border government spending multipliers are found to be monotonically weak for all the subsamples considered. However, foreign output seems to react positively in the short run and when the 1970s have been dropped, but just for the Netherlands, Belgium and Austria.

Overall these findings suggest that fiscal "surprises", in the form of unexpected reductions in taxation and expansions in government consumption and investment, have become progressively less successful in stimulating the economic activity at the domestic level, indicating that, in the framework of the European Monetary Union, policymakers can only marginally rely on this discretionary instrument as a substitute for national monetary policy. Further- 
more, the positive sign of cross-corder multipliers suggests that the interest rate channel of transmission of fiscal policy is offset by the trade one.

\begin{abstract}
This paper documents time variation in domestic fiscal policy multipliers in Germany, the UK and the US, and in cross-border fiscal spillovers from Germany to the seven largest European Union economies. We propose two VAR models which incorporate three "global factors" representing developments in the world economy, and we combine them with identification of fiscal shocks à la Blanchard and Perotti (2002) and Perotti (2005), to study the effects of net tax and government spending shocks on GDP, inflation and interest rates. By recursively estimating these models on different samples of data, we find that the domestic impact of tax shocks has been positive but vanishing for Germany and the US, stably not significant for the UK. Financial markets deregulations may play an important role in that since they allow households to be less dependent on disposable income and to smooth more easily consumption. Domestic government spending multipliers are found to be positive but feeble in the short-run and close to zero or slightly negative in the medium-run, implying that private consumption and investments might be crowded out. These results suggest that, in the European Monetary Union, discretionary fiscal policy "surprises" (i.e. unexpected tax cuts and government spending expansions) cannot be used by governments as substitutes for lost national monetary instruments, since they have shown to be progressively ineffective over time. Finally, we find that fiscal expansions in Germany have had beneficial (though declining) effects for neighboring countries, especially the smaller ones. This may indicate that the trade channel of transmission of fiscal policy dominates the interest rate one.
\end{abstract}

JEL Classification: E30, E61, E62

Keywords: Fiscal policy effectiveness, fiscal shocks, spillovers, factor-augmented VAR, Great Moderation. 


\section{Multiplicateurs Budgétaires NationauX et Transnationaux: COMMENT ILS ONT ÉVOLUÉ EN EUROPE ET AUX ETATS-UNIS}

\section{RÉSUMÉ}

La manière dont la politique budgétaire affecte les économies étrangères dépend de plusieurs facteurs. En particulier, en présence de capacités excédentaires, de politiques monétaires accomodantes, d'une fiscalité distorsive et de contraintes de liquidité, la demande aggrégée réagit positivement à une stimulation budgétaire. L'impact sur les économies étrangères dépend fondamentalement de l'importance des liens commerciaux, de la réaction des taux de change réels et, en union monétaire, de la réactivité de la demande aux taux d'intérêt. Durant les trente dernières années, l'environnement économique de la politique budgétaire a plusieurs fois changé. Par exemple, dans la plupart des pays de l'OCDE, la politique monétaire est devenue moins accomodante dans les années 1980 en comparaison des années 1970, et de nouveau plus accomodante à la fin des années 1990 et au début des années 2000. En outre, les marchés financiers ont été libéralisés. Ainsi, l'impact de la politique budgétaire pourrait avoir évolué au cours du temps.

On examine ici l'évolution, au cours du temps, des multiplicateurs directs et croisés des dépenses publiques et des impôts nets. On analyse l'impact de chocs budgétaires en Allemagne, au Royaume-Uni et aux Etats-Unis sur les économies nationales, ainsi que l'impact des chocs budgétaires allemands sur sept grandes économies européennes. On estime pour cela un modèle vectoriel auto-régressif (VAR) sur la période allant de 1971 à 2004, "augmenté" de trois facteurs représentatifs du cycle de l'économie mondiale. Les résultats montrent que la politique budgétaire a généralement plus d'impact sur le PIB lorsqu'elle passe par une variation des impôts nets que lorsqu'il s'agit d'une variation des dépenses. Ceci pourrait provenir du fait qu'une baisse des impôts élève la croissance potentielle, alors que les dépenses publiques ont plus de chances de se substituer à des dépenes privées. Lorsque les estimations sont menées de manière récursive sur des échantillons de 17 ans, on observe une chute des multiplicateurs à partir des années 1990, surtout en Allemagne (multiplicateurs fiscaux) et aux Etats-Unis (multiplicateurs des dépenses et des recettes). En outre, la conduite de la politique budgétaire semble être devenue moins erratique puisque la variance des chocs budgétaires a diminué, et ceci pourrait expliquer en partie la plus faible volatilité des cycles observée dans les pays de l'étude.

Les externalités de la politique budgétaire allemande sur les pays étrangers apparaissent généralement faibles et non-significatives sur une longue période d'estimation. Cependant, les estimations récursives montrent qu'une baisse des impôts nets en Allemagne a un impact positif, quoique décroissant au cours du temps, sur les pays voisins (France, Italie, Belgique, Autriche), faible et en général non-significatif dans les pays plus éloignés (Royaume-Uni, Espagne). Quant aux multiplicateurs croisés des dépenses, ils apparaissent presque toujours toujours faibles et non-significatifs. L'impact, sur le PIB étranger, d'une hausse des dépenses publiques allemandes est positif lorsqu'on exclut les années 1970, mais seulement aux PaysBas, en Belgique et en Autriche.

Au total, les résultats suggèrent que les "surprises" budgétaires - réductions non-anticipées des impôts nets ou hausses non-anticipées de la consommation ou de l'investissement pub- 
lic - ont de moins en moins d'impact sur l'activité au niveau national. Ainsi, la politique budgétaire discrétionnaire ne semble pas constituer un bon substitut aux politiques monétaires nationales. Par ailleurs, le signe positif des multiplicateurs croisés semble indiquer qu'au sein de l'Union monétaire européenne, le canal des échanges commerciaux l'emporte sur le canal du taux d'intérêt.

\section{RÉSUMÉ COURT}

On examine ici l'évolution, au cours du temps, des multiplicateurs budgétaires en Allemagne, au Royaume-Uni et aux Etats-Unis, ainsi que des multiplicateurs croisés de l'Allemagne vers sept grandes économies européennes. L'analyse repose sur une modélisation VAR en contrôlant l'impact des fluctuations de la demande mondiale. L'identification des chocs d'impôts nets et de dépenses publiques est fondée sur Blanchard et Perotti (2002) et Perotti (2005), et on étudie l'impact de ces chocs sur le PIB, l'inflation et les taux d'intérêt. En estimant de manière récursive ces modèles sur différentes périodes, on trouve que l'impact des chocs fiscaux sur l'économie nationale est positif mais déclinant en Allemagne et aux Etats-Unis, stable mais non significatif au Royaume-Uni. La libéralisation financière a pu jouer dans la mesure où les ménages sont devenus moins dépendants de leur revenu courant et peuvent plus facilement lisser leur consommation au cours du temps. De leur côté, les multiplicateurs des dépenses publiques apparaissent positifs mais faibles à court terme, proches de zéro ou légèrement négatifs à moyen terme, ce qui signifie que la consommation et l'investissement diminuent. Enfin, on montre qu'une politique budgétaire expansive en Allemagne a un effet positif sur le PIB des pays voisins, particulièrement les moins grands d'entre eux. Ceci suggère que, au sein de l'Union monétaire européenne, le canal des échanges commerciaux domine celui du taux d'intérêt.

Classification JEL : E30, E61, E62

Efficacité de la politique budgétaire, chocs budgétaires, externalités, modèle VAR augmenté, stabilisation de l'activité. 


\title{
Changing Patterns of Domestic and Cross-Border Fiscal Policy Multipliers in EUROPE AND THE US ${ }^{1}$
}

\author{
Agnès Bénassy-Quéré2 \\ Jacopo Cimadomo ${ }^{3}$
}

\section{Introduction}

The effectiveness of fiscal policy remains a much debated issue. From an economic policy perspective, it is of crucial importance to know whether fiscal policy might be used as an active tool to dampen economic fluctuations and foster growth. Furthermore, national fiscal policies may spill over to neighbors and trading partners through imports, relative prices and, in a monetary union, common interest rates. This rekindles interest in fiscal policy coordination, provided that cross countries externalities turn out to be relevant.

Recently, a growing body of empirical macroeconomic literature has tried to gauge the effects of fiscal policy measures. Estimates of domestic and cross-border, or "transmission", fiscal multipliers have been derived either through calibrated dynamic general equilibrium models (e.g. Giudice, Turrini and in't Veld (2004) using the QUEST model of the European Commission), through estimated dynamic stochastic general equilibrium models (e.g. Coenen and Straub (2005) and Galí, López-Salido and Vallés (2006)) or through structural vector autoregression (VAR) ones (see for example Blanchard and Perotti (2002), Perotti (2005), Mountford and Uhlig (2002), Beetsma, Giuliodori and Klaassen (2005)). The main advantage of former two classes of models is that they allow to account explicitly for the interrelations among economic variables. However, their results depend heavily on modelling assumptions. VAR models, in turn, are less dependent on theoretical assumptions, but they provide weaker economic interpretations.

The recent literature reviews by Hemming, Kell and Mahfouz (2002) and Briotti (2005) conclude that, at least in the very short run, fiscal policies have some Keynesian effects on domestic economies: a fiscal expansion leads to a rise in national output, although multipliers are generally found to be small. As for fiscal policy spillovers, McKibbin (1997) compares

\footnotetext{
${ }^{1}$ This is a part of the project "Tax/benefit systems and growth potential of the EU" (TAXBEN, Project no. SCS8-CT-2004-502639), financed by the European Commission under FP6 of DG Research. We especially wish to thank Lucrezia Reichlin for helpful discussions. We have also benefited from comments from seminar participants at CEPII, ECARES, ZEI, CPB, Sorbonne, CEPS and in particular Marco Buti, Domenico Giannone, Franc Klaassen, Andrea Nobili, Jan in't Veld and Harald Uhlig. We are grateful to Dietrich Stache of the German Statistical Office for information on the construction of German quarterly series.

${ }^{2}$ CEPII (agnes.benassy@ @epii.fr).

${ }^{3}$ CEPII and ECARES-Université Libre de Bruxelles (jacopo.cimadomo@cepii.fr).
} 
the outcomes from eight large-scale macroeconomic models ${ }^{4}$ on the effects of a US government spending increase (equal to one percent of US GDP) on German GDP to find that cross border multipliers are small and positive (ranging between 0 and 0.5 ) at one year, fading away to zero or becoming negative at a five years horizon.

The literature is rather consensual on the fact that a list of factors may enhance the effectiveness of fiscal policy. For instance, in the case of a fiscal expansion, the impact on domestic output and consumption is stronger in presence of excess capacity, accommodating monetary policy, low government debt, nominal rigidities, when additional public expenditures are not direct substitutes for private spending, when the removed taxes are distortionary and the larger is the share of "Non-Ricardian" (i.e. liquidity constrained) consumers relative to "Ricardian" ones. The impact on foreign output depends on how important are trade links and on other factors. For example, in a monetary union, the size of the interest rate-sensitive component of private investments is of key importance.

Researchers generally agree also in that domestic fiscal multipliers may differ depending on whether fiscal policy is carried out through expenditures or taxes. Due to marginal propensity to save, Keynesian multipliers should be lower for tax shocks than for spending shocks, and this is what many macroeconometric models find. However, spending expansions might be partially crowded out by contractions in private consumption and investments. Furthermore, tax alleviations might have a large and positive impact on consumption (hence on GDP) if rational consumers expect an increase in their permanent income due to reduced distortions in the economy. In sum, tax reductions may prove to be more successful than spending increases in boosting activity, if households have rational expectations and are able to smooth consumption through financial markets. ${ }^{5}$ When measuring the domestic impact of fiscal policy, then, the fact that some of the conditions listed above may have changed over time cannot be discarded. ${ }^{6}$

The dynamic behavior of cross-border multipliers, in turn, will follow that of domestic multipliers if trade spillovers are prominent. However, cross-border multipliers could also be affected by possible time variations in the relative price elasticity of GDP. In addition, the adoption of a new monetary arrangement (especially the move to a monetary union), together with changes in central bank doctrines and in monetary policy transmission channels

\footnotetext{
${ }^{4}$ Notably, the MULTIMOD, INTERMOD A and C, MSGMODEL, TAYLOR, LIVERPOOL, GEM and the QUEST model.

${ }^{5}$ Relying on a VAR methodology, for example, Mountford and Uhlig (2002) find tax multipliers to be higher than spending ones. Bénassy-Quéré (2006), in a two-country New Keynesian model, shows that tax shocks are more effective than spending shocks in presence of a non-accommodating central bank.

${ }^{6}$ For instance, in most OECD countries, monetary policy stance, measured through the evolution of real interest rates, became less accommodating in the 1980s compared to the 1970s, and more accommodating again in the late 1990 and early 2000s. During these decades, government debt has generally increased, the composition of spending and tax policies has varied, financial markets have been deregulated and nominal wage rigidity has increased due to the fact that inflation-indexed contracts have been progressively replaced by unindexed ones. Furthermore, the European economies have moved from the Bretton Woods system to successively the European snake, the European monetary system and finally the European monetary union.
} 
(through for instance the rise in short-term or flexible rate loans) may alter the interest ratedriven spillovers across countries in a monetary union.

Hence, there is no definitive answer on the theoretical evolution of domestic and cross-border fiscal multipliers, and estimating the impact of fiscal policy over a too long period of time might be not appropriate if one (or more) regime shift has occurred.

The issue of time-variation in domestic fiscal policy multipliers has been only partially explored. Blanchard and Perotti (2002) find some instability in multipliers by successively dropping different decades in a sample of US data spanning from 1947 to 1997 . Perotti (2005) studies two separate sub-samples, before and after 1980. More specifically, he shows that, for five OECD countries (US, UK, West Germany, Canada and Australia), the effects of tax and spending shocks on domestic GDP and consumption have decreased during the 1980s and the 1990s relative to previous decades. Some (indirect) evidence of falling domestic multipliers can be also drawn by comparing a first study by Bryant, Henderson, Holtham, Hooper and Symansky (1988) and the follow-up by Bryant, Hooper and Mann (1993) on the crossevaluation of some large scale macroeconomic models used by international institutions. ${ }^{7}$

To our knowledge, a systematic investigation of how cross-border multipliers have evolved over time has not been provided in the literature so far. Clearly, the issue is particularly relevant for those countries having joined the euro and for new candidates.

This paper contributes to the empirical research on fiscal policy effectiveness in three main directions:

i) Methodologically, we combine a "factor-augmented" vector autoregression (FAVAR) approach, recently introduced in the monetary policy literature (see Bernanke, Boivin and Eliasz (2005)), with the identification strategy proposed by Blanchard and Perotti (2002), and Perotti (2005), to provide new evidence on the domestic impact of fiscal policy in three OECD countries: Germany, the UK and the US. ${ }^{8}$ In the two former cases, three "global common factors" representing worldwide comovement in business cycles, credit conditions and fiscal policies are included in a baseline VAR model to control for a possible bias in multipliers estimation due to the fact that worldwide phenomena may affect fluctuations of domestic output, especially in relatively small countries, rather then domestic fiscal shocks.

ii) Second, we extend our workhorse FAVAR model to study fiscal spillovers from the largest Euro area economy - Germany - to five neighboring countries (France, Italy, the Netherlands, Belgium and Austria) and to two more remote countries (Spain and the UK).

iii) Finally, we provide exhaustive evidence on how domestic and cross-border multipliers

\footnotetext{
${ }^{7}$ It is important to note that an evidence of diminishing multipliers might be simply due to a change in the structure of macroeconomic models used by researchers and institutions. Indeed, most models used in the 1970s and the 1980s were Keynesian in that they incorporated adaptive expectations, rigid prices and excess capacity. The latest generation of "New Neoclassical" models uses intertemporal budgeting, forward-looking expectations and removes rigidities in prices and wages, at least in the medium-long-run. These novel features induce fiscal policy to be less effective and multipliers to be smaller. See Hemming, Kell and Mahfouz (2002) and McKibbin (1997) for a discussion on this point.

${ }^{8} \mathrm{We}$ focus on these three OECD countries (Germany, the UK and the US) mainly because reliable (not interpolated) quarterly data for fiscal variables are available only for few industrialized countries. The issue of data reliability will be discussed more extensively in Section 3.
} 
have evolved over time. After analyzing a period ranging between 1971 and 2004, we perform recursive estimations and shocks identification of single-country and two-country models based on rolling windows of data to assess if and how spending and tax multipliers have changed in the last thirty-four years. This exercise is less sophisticated than what proposed by authors using time varying coefficients structural VARs, but it has the advantage in that allows to implement as identification procedure of fiscal shocks based on "institutional", or "out of model", information. We avoid to adopt a simple split of our dataset for two main reasons: first, a breakdate may be improperly imposed or not precisely estimated (see also Boivin and Giannoni (2006)). Second, there might be more than one regime shift. Hence, multipliers may have not varied in a monotonic way.

Our results can be summarized as follows: over the whole sample, we find that domestic tax multipliers are significantly positive and larger than spending ones. Moreover, there is a clear evidence that tax multipliers have been declining whereas spending ones have been substantially stable or, in the US, they have become slightly non-Keynesian in the last part of our sample. German tax shocks do not have beggar-thy-neighbor effects on other European countries. On the contrary, they are likely to impact beneficially on foreign GDP. However this effect seems to be limited to neighboring countries, and it has been fading away since the launch of the euro. Cross-border spending multipliers are very low and rarely significant, except for few countries (Belgium, Austria and the Netherlands) and in the short-run.

The paper is organized as follows. Section 2 presents the methodology, section 3 describes the data, Section 4 and 5 illustrate the results, Section 6 proposes a battery of robustness checks, Section 7 shows a comparison between fiscal VAR and FAVAR models and Section 8 concludes.

\section{Methodology}

\subsection{A "factor-augmented" VAR for fiscal policy analysis}

The standard approach used in the VAR literature to analyze the domestic and crossborder impact of fiscal shocks is to incorporate in the small-scale system a set of endogenous variables including a "fiscal block" (typically taxes, government spending, government deficit or public debt), a "real block" (GDP, industrial production) and a "nominal one" (interest rates, inflation)(see for example Marcellino (2006)). When the focus is on "small open economies" (as the European countries are commonly defined), some authors add to this baseline specification some (few) observable exogenous variables (generally the contemporaneous US output gap or the US GDP) to control for the fact that dynamics in domestic real and nominal variables might be influenced by external forces, and in particular the US business cycle as driver for the world economy, rather than domestic fiscal shocks (see for instance Weyerstrass et al. $\left.(2006)^{9}\right)$. However, the inclusion of US observable economic variables as controls may be inappropriate, possibly leading to biased estimates of reduced form coefficients and impulse responses, on the grounds that:

\footnotetext{
${ }^{9}$ Weyerstrass, Jaenicke, Neck, Haber, van Aarle, Schoors, Gobbin and Claeys (2006).
} 
i) Estimates of output gaps and GDP are importantly affected by measurement error problems; ${ }^{10}$

ii) Albeit the US are certainly the leading world economy, occasional peaks and throughs in the US economic cycle might have been, in some circumstances, only local and temporary, without any major effects on the rest of the world;

iii) The economic cycle in the European countries looks to be not synchronized with the US one, lagging with some quarters (or years) of delay (see Croux, Forni and Reichlin (2001)). This would call for the use of some (indefinite) lags of the US indicator in the system;

iv) Other real and nominal indicators (private consumption and investments, prices, wages, interest rates ... ) might convey more efficient information for the estimation of shocks internationally hitting across countries. ${ }^{11}$

In line with these arguments, one may want to include in the vector autoregression a larger set of variables thought to be useful to explain worldwide economic comovements, but this approach would inevitably suffer from degrees-of-freedom-related problems.

In this paper we borrow from Bernanke, Boivin and Eliasz (2005) and we propose a novel approach which allows to summarize, in a parsimonious way, a large amount of information potentially relevant for an appropriate estimation of a fiscal VAR and of exogenous fiscal shocks, when the economic size of the country of interest is relatively small compared with the rest of the world.

Our approach for the German and British models consists of two steps. ${ }^{12}$ In the first we assume that the world economy, represented by a large number of real and nominal indicators, is driven by few unobservable common factors. We estimate those factors by principal components. Secondly, we include them as "generated regressors" in a fiscal VAR featuring net taxes and government spending as fiscal instruments. Fiscal shocks are identified following Blanchard and Perotti (2002) and Perotti (2005). ${ }^{13}$ We apply this method to estimate the domestic effect of German and UK fiscal shocks, and the cross-border effect of German fiscal shocks on the seven largest European economies.

In particular, let $X_{t}$ be a $N \times 1$ vector of observable economic variables which can be useful to capture worldwide economic phenomena as "world business cycles", "global credit conditions" or "global fiscal expansions or retrenchments". Specifically, $X_{t}$ contains private consumption, private investment, industrial production, changes in stocks, hours, unemployment, labor costs, a fiscal policy indicator (government net lending), consumer prices, three US nominal interest rates and the US composite Dow Jones index (see Appendix A for a de-

\footnotetext{
${ }^{10}$ As regards GDP, data are subject to sizeable revisions for several years following the first release. Output gap measures, on the other hand, can be misleading given the large uncertainty surrounding any estimate of potential output.

${ }^{11}$ In relation with point $i$ and $i v$, see in particular Altissimo, Bassanetti, Cristadoro, Forni, Hallin, Lippi, Reichlin and Veronese (2001).

${ }^{12}$ In the case of the US, we do not augment the model with any global factors due to possible endogeneity.

${ }^{13}$ Contrary to Bernanke, Boivin and Eliasz (2005) we include the estimated factors as exogenous variables only in order to simplify the identification procedure of fiscal shocks. See also Giannone and Lenza (2004) for a related analysis in a panel regression framework.
} 
tailed data description). Importantly, except for interest rates and stock prices, we use not only US variables but also indicators for other OECD non-European Union countries (Canada, Mexico, Japan, Australia, New Zealand, Norway). This should help to capture global shocks that may originate in the US economy or in another area of the world. Moreover, this should allow to control for possible time lags in the trans-national propagation mechanism of those shocks: if cyclical indicators in quarter $t$ rise not only in the US but also, say, in Japan, then it is likely that the shock is global and spreads contemporaneously. European Union countries are not incorporated in the panel to avoid any endogeneity problem, since it cannot be discarded that a fiscal shock in a country of the Union could affect both the domestic output and that of neighboring countries. As far as interest rates are concerned, just US variables have been used. Indeed, there is little ambiguity on the fact that the US monetary policy has been the key force in explaining worldwide credit and money market conditions over the last thirty years. Finally, we include a fiscal policy indicator since a fiscal expansion elsewhere in the world may spur the German and UK GDP.

We are left with 51 time series that can be used to extract few pervasive common forces likely to drive the world economy. In particular, we assume that $X_{t}$ follows a factor structure as:

$$
X_{t}=\Lambda F_{t}+\xi_{t}
$$

where $F_{t}$ is a $R \times 1$ vector of common factors $(R<<N), \Lambda$ is an $N \times R$ matrix of factor loadings and $\xi_{t}$ is a $N \times 1$ vector of (weakly correlated) idiosyncratic components. We estimate $F_{t}$ as the first $R$ static principal components of the covariance matrix of $X_{t}$ (see Stock and Watson (1998)). This approach, as widely documented in the factor model literature (see for example Reichlin (2002) and Forni, Hallin, Lippi and Reichlin (2002)), is particularly successful in capturing, in a parsimonious way, comovements between a large number of variables.

We select the "static rank" $(R)$ equal to three, since the first three principal components explain more than $60 \%$ of the variability in our panel. ${ }^{14}$

Then, in order to explore the transmission of German, UK and US domestic fiscal shocks to domestic economies, we propose a five-variables VAR model in real net taxes per capita $(n)$, real government spending per capita $(g)$, real GDP per capita $(y)$, GDP deflator inflation rate $(p)$ and the 10-years nominal interest rate ( $i$ ) (see Appendix B on data construction), as in Perotti (2005). However, for Germany and the UK, the benchmark model is "augmented" by the three common factors estimated in the first step:

$$
Y_{t}=A(L) Y_{t-1}+B F_{t}+C W_{t}+u_{t}
$$

where $Y_{t}$ is the $M \times 1$ vector of endogenous variables, $L$ is the lag operator for $A(L)=$ $1-A_{1} L-\ldots-A_{k} L^{k}, F_{t}$ the $R \times 1$ vector of estimated latent factors, $B=\left[b_{1}, b_{2}, b_{3}\right]$ where $b_{i}$ is a $M \times 1$ vector of factor loadings, $u_{t}$ the $M \times 1$ vector of correlated reduced-form residuals and $W_{t}$ a vector of additional exogenous variables including a constant and, for the German model, an impulse dummy on 1991:1 to control for the German reunification as in

\footnotetext{
${ }^{14}$ Section (6) shows some robustness exercises where the vector autoregression is augmented by one latent factor only $(R=1)$.
} 
Lütkepohl and Wolters (2003) and Brueggemann and Lütkepohl (2004). ${ }^{15}$ Next, model (2), hereafter labeled as "single country model", is estimated equation by equation by OLS for $k=4$, given the quarterly nature of the series employed. ${ }^{16},{ }^{17}$

As already mentioned, the model for the US economy does not include any factors as additional regressors since possible endogeneity problems may easily arise: even if ideally we could extract some factors from (1) estimated, say, on European data, it would be unclear whether an upturn in European cyclical indicators would be driven by US shocks or by shocks originated elsewhere.

Finally, to study the effects of German fiscal shocks on other European countries $j$, the singlecountry German model based on (2) is appended by two "peripheral" variables representing the foreign real GDP $\left(y_{t}^{j}\right)$ and the foreign country real effective exchange rate $\left(e r_{t}^{j}\right)$ :

$$
\left[\begin{array}{c}
Y_{t}^{g e r} \\
y_{t}^{j} \\
e r_{t}^{j}
\end{array}\right]=\tilde{A}(L)\left[\begin{array}{c}
Y_{t-1}^{g e r} \\
y_{t-1}^{j} \\
e r_{t-1}^{j}
\end{array}\right]+\tilde{B} F_{t}+\tilde{C} W_{t}+\left[\begin{array}{c}
u_{t}^{g e r} \\
u_{t}^{y^{j}} \\
u_{t}^{e r^{j}}
\end{array}\right]
$$

where $F_{t}$ is estimated as before and $\tilde{B}=\left[\tilde{b}_{1}, \tilde{b}_{2}, \tilde{b}_{3}\right]$, where $\tilde{b}_{i}$ is a $(M+2) \times 1$ vector of factor loadings. We focus on the seven largest EU economies (France, United Kingdom, Italy, Spain, Netherlands, Belgium, Austria), we include $y_{t}^{j}$ and $e r_{t}^{j}$ in (3) successively for each country and we estimate the resulting systems (which in the following are referred to as "two-country models") equation by equation by OLS.

The issue of fiscal shocks identification will be addressed at length below. Focusing now on estimation results for the reduced form models (2) and (3), Table 2 shows the marginal contribution of incorporating a richer information set, as summarized by the estimated latent factors $F_{t}$, into a fiscal VAR framework. Columns (1) to (3) display the absolute values of the $t$ statistic associated with the factor loadings $B$, for each equation in single country models, and $\tilde{B}$, for the foreign GDP equation in two country models. The first factor turns out to be highly significant in the German model for all the five endogenous variables, the second factor only for the inflation equation and the third one for the net taxes, GDP and interest rate equations. As for the UK model, the first factor seems to be important in explaining GDP dynamics, the second looks relevant for government spending and interest rate equations and the third is highly significant for interest rates. In two-country models, the coefficients on the first and third factors are generally significant whereas the absolute values of the $t$ statistics

\footnotetext{
${ }^{15}$ Quarterly dummies have also been added to the vector of control variables but they turn out to be not significant.

${ }^{16}$ In the baseline exercise, after conducting a battery of unit root tests to check for stationarity, the model is estimated using first differences of the data. Table 1 reports results for the Augmented Dickey Fuller (ADF) and Elliott, Rothenberg and Stock (1996) (ERS) tests. The latter allows for a level shift in variables, and it is used to control for German reunification effects. Indeed, both the ADF and the ERS tests speak strongly against stationarity (with the exception of the UK interest rate, but we treat it as well as non-stationary for consistency with the other countries under examination). Section 6 provides a battery of robustness checks for alternative transformation of data and lag structure.

${ }^{17}$ Note that model (2) incorporates "generated" regressors. We rely on the arguments set forth by Bai (2003) and we treat the estimated factors as known.
} 
associated with $\tilde{b}_{2}$ is always below the $95 \%$ significance level. Models incorporating GDP for France, Italy and Belgium seem to be the more affected by the inclusion of latent common factors in the regressions; the ones including the GDP of the Netherlands and the UK GDP the least.

Columns (4) to (6) show the marginal improvement in the model fit, as represented by the adjusted $R^{2}$ statistic (which contains a penalization term for additional independent variables used in the regression), compared with VARs including only US GDP and the US Federal Fund Rate as control variables (VAR+US) and with simple VAR without any exogenous variable representing global factors. In each equation, in single country and two country models, the fit improves when latent factors are used as additional explanatory variables (with the exception of the model incorporating the Dutch GDP). Notably, the adjusted $R^{2}$ increases remarkably for GDP equations in the single country models (especially the UK one) and for the French GDP, in the corresponding two country model. Finally, the Akaike Information Criterion (AIC) (which, again, penalizes the addition of extra regressors), shown in columns (7) to (9), is always minimized when the VARs are augmented by $F_{t}{ }^{18}$

Overall these results suggests that, if (2) and (3) are the "true" data generating models, omitting the information contained in $X_{t}$ and $F_{t}$ would contaminate the estimation of the model parameters and, consequently, of some quantity of interest as impulse response coefficients. ${ }^{19}$ Furthermore, even though the purpose of this study is not the forecast of fiscal variables, results in Table 2 seem to indicate that the FAVAR specification outperforms the two competing models, at least in-sample.

\subsection{Single country model: shocks identification}

The identification of fiscal shocks in our single country models relies on Blanchard and Perotti (2002) and Perotti (2005). The strategy consists of using "institutional" and economically meaningful information to pin down some relations linking the reduced form residuals $u_{t}$ and the "structural", uncorrelated shocks, that we label as $\varepsilon_{t} \cdot{ }^{20}$ Defining as $M 1$ and $M 2$ the matrices of coefficients linking the vectors of reduced form and structural residuals:

$$
M 1 u_{t}=M 2 \varepsilon_{t}
$$

the idea is to calibrate some coefficients in $M 1$ and $M 2$ using "out of model" information and to estimate the remaining ones, under a condition of orthogonality on the resulting (unobserved) structural shocks. Rewriting (4):

\footnotetext{
${ }^{18} \mathrm{We}$ also make the experiment of estimating common factors on a panel of real variables only, and including the US interest rate as additional observable factor. Results are in line with Table 2 in that the FAVAR model outperforms the VAR+US model.

${ }^{19}$ Section 7 will be devoted to a comparison of "structural" impulse response functions from the three competing models.

${ }^{20}$ This approach was originally proposed by Shapiro and Watson (1988). A related application, in the field of monetary policy analysis, is Bernanke and Mihov (1998).
} 


$$
\left[\begin{array}{ccccc}
1 & 0 & \alpha_{n y} & \alpha_{n p} & \alpha_{n i} \\
0 & 1 & \alpha_{g y} & \alpha_{g p} & \alpha_{g i} \\
\gamma_{y n} & \gamma_{y g} & 1 & 0 & 0 \\
\gamma_{p n} & \gamma_{p g} & \gamma_{p y} & 1 & 0 \\
0 & 0 & \gamma_{i y} & \gamma_{i p} & 1
\end{array}\right]\left[\begin{array}{c}
u_{t}^{n} \\
u_{t}^{g} \\
u_{t}^{y} \\
u_{t}^{p} \\
u_{t}^{i}
\end{array}\right]=\left[\begin{array}{ccccc}
1 & \beta_{n g} & 0 & 0 & 0 \\
\beta_{g n} & 1 & 0 & 0 & 0 \\
0 & 0 & 1 & 0 & 0 \\
0 & 0 & 0 & 1 & 0 \\
\beta_{i n} & \beta_{i g} & 0 & 0 & 1
\end{array}\right]\left[\begin{array}{c}
\varepsilon_{t}^{n} \\
\varepsilon_{t}^{g} \\
\varepsilon_{t}^{y} \\
\varepsilon_{t}^{p} \\
\varepsilon_{t}^{i}
\end{array}\right]
$$

We proceed as follows: first, a set zeros restrictions are imposed on $M 1$ and $M 2$ under the assumption that unexpected movements and structural shocks to same variables do not have any effects on unexpected movements in other variables. For instance, due to transmission delays, it is assumed that $u_{t}^{p}, u_{t}^{i}, \varepsilon_{t}^{p}$ and $\varepsilon_{t}^{i}$ do not have any contemporaneous effect on unforecastable changes in output $\left(u_{t}^{y}\right)$ and that $\varepsilon_{t}^{p}$ and $\varepsilon_{t}^{i}$ do not affect unexpected inflation variations $\left(u_{t}^{p}\right)$.

Secondly, the $\alpha$ parameters are pinned down using "institutional" information. In particular, the parameter $\alpha_{n y}$ represents the contemporaneous reaction of fiscal policy to changes in GDP. The key step in the identification procedure consists in the calibration of this parameter and relies on the fact that a short-term reaction of $u_{t}^{n}$ to $u_{t}^{y}$ should be anything else than automatic stabilization. In other words, an unexpected rise in taxes in quarter $t$ following an unexpected increase in GDP in quarter $t$ is not likely to be consequence of a discretionary fiscal action, since fiscal authorities need time to observe GDP movements, to approve possible stabilizing measures, and to implement them.

Lastly, the $\gamma$ parameters are derived by recursively regressing, starting from the first equation, residuals $u_{t}^{z}$ on $u_{t}^{j}$ and $\varepsilon_{t}^{j}$ (for $z \neq j$ ).

An intuitive way to read the equations in this system is to think of them as reaction functions. The first equation, for instance, implies that net taxes respond automatically to contemporaneous and lagged innovations in output, prices and the interest rate, and that they also discretionarily react with a lag to the same shocks. Furthermore, they move in response to random discretionary shocks to fiscal variables. The last equation can be interpreted as an "augmented Taylor-rule" where interest rate movements follow changes in output and prices, but also in fiscal variables, beside being determined by exogenous monetary shocks $\varepsilon_{t}^{i}$.

By estimating the output and price sensitivities of single items adding up to the public receipts indicator $n$, we obtain $\alpha_{n y}$ equal to 1.38 for Germany, 1.33 for the UK and 1.41 for the US. As for $\alpha_{n p}$, we get respectively 1.05, 0.93 and 1.16 (see Appendix $\mathrm{C}$ for elasticities construction). The price elasticity of real spending is set equal to -0.5 . This figure is based on the fact that at least half of nominal public spending (basically wages) are not reacting to price increases within the same quarter whereas the other half (purchases of goods and services, notably drugs and health-related expenditures) is perfectly indexed. When converting public spending into volumes, we end with a -1 elasticity in the first case and a 0 elasticity in the second one, hence to an average of -0.5 . As in Perotti (2005), we assume that $\alpha_{n i}, \alpha_{g y}$ and $\alpha_{g i}$ are zero, since there is no reason to predict that taxes and spending respond in the same quarter to movements in the interest rate and that spending should respond contemporaneously to output. We are left with a vector of orthogonal structural shocks $\varepsilon_{t}$, with an economically meaningful interpretation. 


\subsection{Two-country model: shocks identification}

In two-country models (3), we assume that the two equations linking reduced form and structural residuals from the foreign block and the German one are: ${ }^{21}$

$$
\begin{aligned}
& u_{t}^{y^{j}}=\gamma_{y^{j} n} u_{t}^{n}+\gamma_{y^{j} g} u_{t}^{g}+\gamma_{y^{j} y} u_{t}^{y}+\gamma_{y^{j} p} u_{t}^{p}+\gamma_{y^{j} i} u_{t}^{i}+\varepsilon_{t}^{y^{j}} \\
& u_{t}^{e r^{j}}=\gamma_{e r^{j} n} u_{t}^{n}+\gamma_{e r^{j} g} u_{t}^{g}+\gamma_{e r^{j} y} u_{t}^{y}+\gamma_{e r^{j} p} u_{t}^{p}+\gamma_{e r^{j} i} u_{t}^{i}+\gamma_{e r^{j} y^{j}} u_{t}^{y^{j}}+\varepsilon_{t}^{e r^{j}}
\end{aligned}
$$

Considering the whole two-country model we have:

$$
\begin{gathered}
{\left[\begin{array}{ccccccc}
1 & 0 & \alpha_{n y} & \alpha_{n p} & \alpha_{n i} & 0 & 0 \\
0 & 1 & \alpha_{g y} & \alpha_{g p} & \alpha_{g i} & 0 & 0 \\
\gamma_{y n} & \gamma_{y g} & 1 & 0 & 0 & 0 & 0 \\
\gamma_{p n} & \gamma_{p g} & \gamma_{p y} & 1 & 0 & 0 & 0 \\
0 & 0 & \gamma_{i y} & \gamma_{i p} & 1 & 0 & 0 \\
\gamma_{y^{j} n} & \gamma_{y^{j} g} & \gamma_{y^{j} y} & \gamma_{y^{j} p} & \gamma_{y^{j} i} & 1 & 0 \\
\gamma_{e r^{j} n} & \gamma_{e r^{j} g} & \gamma_{e r^{j} y} & \gamma_{e r^{j} p} & \gamma_{e r^{j} i} & \gamma_{e r^{j} y^{j}} & 1
\end{array}\right]\left[\begin{array}{c}
u_{t}^{n} \\
u_{t}^{g} \\
u_{t}^{y} \\
u_{t}^{p} \\
u_{t}^{i} \\
u_{t}^{y^{j}} \\
u_{t}^{e r^{j}}
\end{array}\right]=} \\
\\
{\left[\begin{array}{ccccccc}
1 & \beta_{n g} & 0 & 0 & 0 & 0 & 0 \\
\beta_{g n} & 1 & 0 & 0 & 0 & 0 & 0 \\
0 & 0 & 1 & 0 & 0 & 0 & 0 \\
0 & 0 & 0 & 1 & 0 & 0 & 0 \\
\beta_{i n} & \beta_{i g} & 0 & 0 & 1 & 0 & 0 \\
0 & 0 & 0 & 0 & 0 & 1 & 0 \\
0 & 0 & 0 & 0 & 0 & 0 & 1
\end{array}\right]\left[\begin{array}{c}
\varepsilon_{t}^{t} \\
\varepsilon_{t}^{g} \\
\varepsilon_{t}^{y} \\
\varepsilon_{t}^{p} \\
\varepsilon_{t}^{i} \\
\varepsilon_{t}^{y^{j}} \\
\varepsilon_{t}^{e r^{j}}
\end{array}\right]}
\end{gathered}
$$

This specification implies that domestic German fiscal shocks propagate abroad through interest rate, demand, and relative price channels, and through other (unspecified) possible channels, as financial markets, represented by the fact that $u_{t}^{n}$ and $u_{t}^{g}$ enter directly in the equation of foreign output (see Canzonieri, Cumby and Diba (2003) for a similar approach). It also implies that an ordering between the largest Euro Area country and remaining ones is imposed: foreign GDP is assumed to have no contemporaneous impact on German fiscal variables. $^{22}$

Parameters $\alpha$ are calibrated as in the previous section, and the $\gamma$ ones are estimated. By construction, the residuals $\varepsilon_{t}^{y^{j}}$ and $\varepsilon_{t}^{e r^{j}}$ result to be orthogonal to the vector of German structural shocks.

\footnotetext{
${ }^{21}$ The index "ger" has been suppressed for the German variables to simplify the notation.

${ }^{22}$ This assumption seems plausible for smaller countries, but might be questionable when spillovers to France and UK are analyzed. However, considering the leading role of Germany in driving the European economic cycle, we consider such an approach to make sense.
} 


\section{The Data}

As extensively illustrated in the empirical literature on monetary policy, small-scale multivariate models (such as VARs and FAVARs) offer an interesting framework to trace out the impact of policy shocks on the economy. One limitation in using these econometric tools is however the need of data with a relatively high frequency (monthly or quarterly) in order to avoid degrees-of-freedom problems in estimation and because the most popular identification procedures relies on discarding a number of short-run contemporaneous relationships. In particular, in this paper, identification hinges on the assumption that taxes do not react in the same quarter to output fluctuations as a consequence of discretionary policy actions.

The lack of high-enough-frequency data for fiscal variables reduces the scope for applying a VAR-type of methodology to several countries. However, some OECD countries provide reliable (not interpolated from annual figures) quarterly data on key budget items since the beginning of the 1970s and, in the US case, even before (see OECD Economic Outlook No. 78 (2005) database inventory and Perotti (2005)).

Even when data reliability is made certain for some countries, some objections have been raised on the use of quarterly data for fiscal policy analysis, on the ground that fiscal policy requires long decisions and implementation lags. In line with some authors working on fiscal policy empirics (notably Perotti (2005)), we consider that the use of quarterly data makes sense since: $i$ ) albeit there is one budget yearly, governments are able to take decisions with fiscal impact along the year; ii) quarterly data almost correctly reflect fiscal policy in an economic (accrual) rather than cash sense.

Here we rely on these arguments and we use OECD quarterly accounts data (from the OECD Economic Outlook No. 78, December 2005 Issue) ranging between 1971-first quarter and 2004-fourth quarter for the construction of the two fiscal indicators employed in the paper (see the construction of each variable in Appendix B). By studying in details the way in which the fiscal series of interest are constructed for the three countries under scrutiny (Germany, the UK and the US), we find that only in few cases quarterly series are pure interpolation from annual data. Specifically, UK and US quarterly fiscal data are generally considered to be very reliable. As concerns Germany, indicators used for the computation of GDP (government consumption, government fixed capital formation), but also direct taxes on households and on business, have been published on a quarterly basis by the German Statistical Office for the whole period of time covered in this study. ${ }^{23}$ Only data on transfers, defined in the present framework as subsidies to firms plus social security benefits paid by the government, are fraught with some uncertainty. However, they have been published on a quarterly frequency since 1999 (by the OECD and EUROSTAT) and before 1991, for West Germany. Overall, it can be argued that the three countries under scrutiny have a large amount of "genuine" quarterly information in their data. ${ }^{2425}$

\footnotetext{
${ }^{23}$ For years before 1991 , only West Germany data are available.

${ }^{24}$ Note that Weyerstrass et al. (2006), in a VAR framework, use quarterly data for fiscal balances (which comprise, by construction, government spending, revenues and transfers) for Germany and the other main Euro Area countries on a sample including the 1980s.

${ }^{25}$ Appendix B presents in details the description and sources of all the endogenous variables used in
} 


\section{Domestic effects of fiscal shocks}

\subsection{Full sample estimation}

Impulse response functions (IRFs) for the three single country models and a sample spanning from 1971:1 through 2004:4 are reported in Figures 1 to 3. Red lines represent the baseline IRFs and black lines the $90 \%$ confidence intervals. ${ }^{26}$ Fiscal shocks are always normalized to be equal to one percent of domestic GDP. The reaction of other variables can be interpreted as percentage change (fiscal variables, output) or as percentage point changes (inflation, interest rate).

In Germany (Figure 1), an exogenous tax cut has a positive, significant and persistent impact on output, and the GDP multiplier is close to one. After one year, public expenditures react downwards, but this is not enough to erase the deficit. Despite higher budget deficit and inflation, the long-run interest rate does not react to the shock. Conversely, an exogenous spending rise has a weaker, and not significant, impact. Inflation rises slightly, but just in the very short run, due probably to the fact that pressures on prices coming from higher public expenditures more than compensate the drop in private consumption. The sign of impulse coefficients on the interest rate is positive, indicating that the central bank might react to a worsening in public finance. As for the UK (Figure 2), tax shocks boost GDP up to one year. The GDP multiplier, equal to 0.23 in the short run, is lower than in Germany and ebbs away after one year. Spending shocks spur inflation and interest rates, but they do not seem to have sizeable effects on output. Figure 3 zooms in on the reaction of US variables to domestic fiscal impulses: tax shocks elicit a positive response of GDP in the medium horizon, when multipliers are close to one (though not very precisely estimated). Government spending shocks, on the contrary, have a significant effect just on impact (GDP increases by 1.07 percent in the first quarter).

On the whole, we find that spending shocks are relatively ineffective in moving output in the countries under scrutiny (except for the US, in the short run) whereas net tax shocks seem to have a more significant and persistent impact. This is consistent with a "supply-side" interpretation in that, since tax policies (as opposed to spending policies) may rise potential growth in the long run, they have a positive impact on consumption, hence also on output in the short run. ${ }^{27}$ Spending shocks have weaker effects since they are more likely to crowd out private demand, generally due to interest rates and inflation reacting upwards (see the UK case).

To be noted, an analysis based on such a long sample of observations might be contaminated by the presence of one (or more) structural breaks in the variables and in the relations

\footnotetext{
model (2) and (3).

${ }^{26}$ Note that these confidence intervals are more restrictive than the $68 \%$ bands used by Blanchard and Perotti (2002), Perotti (2005) and Canzonieri, Cumby and Diba (2003).

${ }^{27}$ However, it should ne noted that a net tax cut can also correspond to a rise in public transfers that can have a positive, a negative or no impact on potential output depending on the type of transfer (e.g. health versus minimum income transfers). In this case our results seem to reveal that the crowding out effects from shocks on public consumption and investment dominate the (uncertain) effects from variations in public transfers.
} 
among them. To test for the possibility that fiscal policy multipliers have changed over time, Perotti (2005) splits his sample into two parts and finds that the post-1980 period is characterized by weaker fiscal multipliers. However, even though a breakdate located around 1980 is consistent with several macroeconomic studies, this threshold is generally quite imprecisely estimated. ${ }^{28}$ Moreover, it is not obvious whether the change takes the form of a single structural break rather than a process lasting for some quarters, or years. Finally, as argued before, more than one regime change may occur over a long period of time.

To check whether there is statistical evidence of a single break date in the model parameters, we apply a simple Chow (1960) test to each reduced-form equations in single countries' FAVARs specified in (2), as in Ahmed, Levin and Wilson (2004). Results are reported in Table 3 for eight possible break dates between 1979:1 and 1993:1 (1985:1 for Germany). ${ }^{29}$ As regards the German model, the $p$-values associated with the test indicate the presence of a possible structural break in 1979:1 for two equations in the model (net taxes and inflation). However, the remaining three equation show no significant discontinuity in the estimated coefficients. Results for the UK are on the opposite side, revealing a lot of instability in the model. Nevertheless, break dates could be equivalently located during the whole 1980s. Tests applied to US data indicate that a sample split might be located at the beginning of the 1980s but also in this case the uncertainty surrounding the estimation of a possible break date is large since the threshold could be equally set during (at least) four years.

\subsection{Evolving domestic multipliers: recursive analysis}

Section 4.1 showed that our data do not speak clearly in favor of a single break date. Thus, in order to avoid losing information and to capture some possible non-monotonic effects in fiscal multipliers time variation, we perform recursive estimations and shocks identification of single country models (2). In particular, we start from the sample [1971:1,1987:4] and we repeat estimation and identification of fiscal shocks by moving the staring date by one quarter and keeping the sample size constant to 17 years. ${ }^{30}$

\footnotetext{
${ }^{28}$ Boivin and Giannoni (2006), for example, apply the Bai, Lumsdaine and Stock (1998) multivariate stability test to a quarterly VAR for the US economy estimated over the period 1959:1 to 2002:2. They find that the $90 \%$ confidence interval for the VAR parameters break date ranges between 1977:4 and 1986:2.

${ }^{29}$ The sample for Germany ends in 1990:4 since the Chow (1960) test does not allow to nest two different models, one including an impulse dummy for 1991:1 to control for the reunification, and the other without any dummy variable.

${ }^{30}$ This exercise is similar to Canova (2006) who recursively estimates a DSGE model to explore possible changes in the conduct of the US monetary policy, but in each step not only we estimate the system, we also implement shocks identification. This approach has a low level of econometric sophistication but has the advantage that identification à la Blanchard and Perotti (2002), which represents "state of the art" approach to achieve identification of budgetary impulses, is implementable at each step. More sophisticated approaches, as the Bayesian one proposed by Primiceri (2005), require that covariance matrix of reduced form residuals is drifting and it is estimated for each $t$. This however would be hardly conceivable with the identification strategy shown in sections (2.2) and (2.3), where a certain decomposition of the covariance matrix of these residuals is imposed using external information.
} 
Figures 4, 5 and 6 trace out GDP impulse responses for Germany, the UK and the US over different samples and horizons. In Germany, a clear downward pattern in the impact of net tax shocks emerges since the mid-1980s (Figure 4a), whereas spending shocks (Figure 4b) seem more effective during the first two decades considered, compared to samples including the 1990s. As concerns the UK, the reaction of GDP to tax shocks (but also spending ones) looks quite monotonic except for a drop in end-1980s samples. The US case shows that governments were very effective in spurring the economic activity through tax cuts up to the beginning of the 1990's, but became less effective afterwards. Moreover, fiscal policy implemented through spending increases seems to become more and more non-Keynesian in that it brings about a fall in output over the last samples.

This kind of analysis, clearly, does not allow to draw any conclusion on the significance of these bunches of impulse responses. Then, to have a better insight on how the effects described above are relevant (in a statistical sense) or not, we plot the one-quarter and the eightquarters IRFs for all our samples, and we use markers to indicate $90 \%$ significance. Figures 7 to 9 illustrate our findings. In particular, Figure 7a shows that the impact of a German net tax shocks follows a hump-shape curve over time, with a pick during the 1980s. Afterwards, the short run and especially two-year multiplier tends to decline, the latter becoming non-significant at the end of the period. Spending shocks seem to be not relevant in affecting GDP, except for the last period and for the short-run (first quarter) when the GDP multiplier is close to unity. As for the UK, tax policies show some (weakly) significant and Keynesian effects just in the first part of the sample, and for the short-run (Figure 8a). Finally, Figure 9 a indicates that a remarkable drop in the US two-year tax multiplier from values larger than one to zero emerges as far as the 1990s are included in the estimation samples.

In the three countries and in most sub-periods, the impact of fiscal shocks on the long term interest rate is rarely significant (an exception are the UK spending shocks, but just for the more recent periods). Conversely, fiscal expansions have generally positive effects on GDP, albeit this is more the case of a net tax cut than of a spending expansion. In the latter case, the strong crowding out observed (i.e. the multiplier is hardly significant) seems to pass through other channels than inflation or the interest rate, and this is consistent with a Ricardian-type interpretation in that consumers save more expecting future increases in taxes to repay public debt.

\subsection{Recursive GDP variance decomposition}

Next, we assess how important fiscal shocks have been in contributing to GDP dynamics by implementing a forecast error variance decomposition exercise over the rolling samples of data and different horizons. Figure 10 shows that, in Germany, net tax shocks explain up to 40 percent of output variability in the 1980s and beginning of 1990s. Spending shocks contribute to less than 6 percent over almost the whole period of observation, except for the beginning of the sample and a (minor) peak when early 1990s are considered. These two findings may be related to the German reunification that involved large fiscal shocks, both on the spending side and on the net-tax (transfer) one. Results for the UK (Figure 11) and the US (Figure 12) are even more informative, pointing to a virtually ineffective role of (unsystematic) fiscal 
policy in more recent years: in the UK, fiscal shocks account for at most $10 \%$ of GDP forecast error variance up to the end of the 1980s, less than $2 \%$ afterwards. In the US, both net taxes and spending shocks contribute to less than $5 \%$.

To be noted, variance decomposition results depend on the size of impulse response coefficients in the moving average representation of the FAVAR but also on the variance of structural shocks. Thus, some indirect evidence can be drawn from Figures 10 to 12 on the fact that fiscal shocks seem to have become less volatile. In the light of the recent debate on the "Great Moderation", suggesting a more virtuous monetary policy as the main cause behind the observed drop in the volatility of economic activity during the last 30 years (see for example Stock and Watson (2003)), our results indicate that a less erratic conduct of fiscal policy may have also contributed to dampen fluctuations in the economic cycle.

\section{Cross-border effects of German fiscal shocks}

\subsection{Full sample estimation}

The impact of German fiscal shocks on the seven largest European countries is reported in Figure 13. The top panel shows that the tax spillover effect seems to be generally positive, but significant just for France, the UK and the Netherlands in the short-run. On the other hand, an increase in German government spending spurs output in Italy, but just in the short-run. French GDP is significantly hampered when German public expenditure grows, possibly due to the rise in German interest rates (and Euro Area ones, in the most recent subsamples) and to the appreciation of the French real exchange rate (prices in Germany fall, slightly, following a shock to $g$ ). Cross-border spending multipliers are rarely significant for the remaining countries, with the exception of Italy, but again just in the first quarter.

\subsection{Evolving cross-border multipliers: recursive analysis}

As before, this kind of analysis might be affected by the presence of structural breaks and regime shifts. Hence, we proceed as in the previous sections and we compute impulse responses from recursive estimations of model (3), where identification of fiscal shocks is achieved based on (8) for each subperiod. Figure 14 (impulse responses over each subsample, successively) and 16 (significant 1-quarter and 8-quarters impulse responses signalled with markers) highlight that cross-border net tax multipliers follow a similar hump shape as the domestic German multiplier, i.e. they have their maxima for windows ranging from 1977 to 1998. In addition, neighboring countries seem to be the most affected whereas "remote" ones (UK and Spain) the least (see Figure 16). This is consistent with the view of dominant trade spillovers: since interest rate are not significantly raised for almost all subsamples (see Figure 7), a tax cut in Germany has a positive impact on these countries possibly through higher German imports, whereas an interest-rate reaction would have affected all ERM countries, being they close or not to Germany. In the last windows (which include the EMU period), however, cross-border tax multipliers turn non-significant even in the short term, whereas the 
domestic multiplier of Germany stays significant, albeit at a lower level. The fall in crossborder multipliers may be related to the reduction in the share of Germany as a destination for neighboring countries' exports. Indeed, from 1992 to 2005, the share of Germany in total exports fell from $39.8 \%$ to $31.2 \%$ in Austria, from $17.2 \%$ to $14.7 \%$ in France, from $20.3 \%$ to $13.1 \%$ in Italy and from $29.0 \%$ to $24.9 \%$ in the Netherlands. ${ }^{31}$

Turning to spending spillovers, Figure 15 and 17 shows that they are significant in the shortrun and in the second half of the sample, but just for Austria, Belgium, the Netherlands and, partially, the UK. This might depend on the fact that the domestic, one-quarter, multiplier becomes positive and significant in Germany in the late sub-periods. Strikingly, though, cross-border multipliers are not significant over all subperiods in France and Spain, and over the second half of the sample in Italy.

\subsection{Recursive variance decomposition: foreign GDP}

Recursive forecast error variance decompositions for each country's GDP are reported in Figures 18 and 19, displaying the contribution of German fiscal shocks to variability in foreign economic activity. Net tax shocks in Germany explain up to $12 \%$ of GDP variance in the UK in the 1970s and 1980s, and up to at most 10\% in Italy, Belgium and Austria in central subsamples (including end of 1970s and early 1990s). The Netherlands seems more affected but, again, only as long as the end of the 1990s are not included in the analysis. Afterwards, the share of GDP variance accounted for by German tax shocks declines drastically and it is close to zero in the more recent periods. As for German spending shocks, the largest contributions are associated to early subsamples (1970s to mid 1980s), and again they decline impressively when the end-1990s are added in.

\section{Robustness checks}

Table 4 reports the outcomes from some robustness exercises. In particular, it shows the first quarter (1q) and two years (8q) GDP multipliers estimated through five different specifications of the single country and two-country models. Columns (1) and (2) summarize the results from the baseline model, based on impulse responses in Figures 1 to 3 and 13. Columns (3) and (4) present results for models incorporating only one lag in the autoregressive structure, to check whether the estimation uncertainty due to a large number of parameters in the baseline specification may alter the results. Short run multipliers turn out to have always the same sign, and a very similar size, compared to the value reported in the first column. The tax shock is more persistent for the UK, as indicated by a significantly higher two years multiplier. When the models are estimated in levels, short term multipliers are very close to the benchmark ones. However, the tax shock for Germany looks less persistent, fading to a value close to zero in the medium run.

Next, since the estimation of output and price elasticity of net taxes represents always a thorny task (the assumption of constant elasticities is itself questionable, given the evolution

\footnotetext{
${ }^{31}$ Source: International Monetary Fund, Direction of Trade.
} 
over time of the quantities of interest), we repeat the exercise by replacing our elasticities estimates with the one provided in the paper by Perotti (2005). Interestingly, domestic and cross-border multipliers are very close to what obtained using our baseline specification. Net tax multipliers in the UK domestic model are, nevertheless, slightly lower.

Finally, we compute GDP impulse responses by adding just one factor in the German and UK single country FAVAR, and in the two country model (Table 2 showed that the first factor seems to be the most important in explaining GDP dynamics). Results summarized in columns (9) and (10) indicate no substantial differences compared to the benchmark estimates.

\section{Comparing fiscal VAR and FAVAR models}

As discussed above, Table 2 points to a better performance, in terms of data fit, of the FAVAR incorporating three unobservable common factors for the world economy compared with a VAR augmented by US key variables only and with a VAR without any controls representing global economic phenomena. For single country German and UK models, Figure 20 zooms in on the marginal difference in terms of IRFs and variance decomposition stemming from the inclusion of factors in the VAR. Figure 20a shows that the GDP impulse responses tend to be similar across the three different specifications proposed. As concerns government spending shocks, however, the inclusion of the US GDP and Federal Fund Rate induces higher GDP multipliers, compared with the simple VAR, whereas the FAVAR model leads to lower multipliers. To be noted, the contribution of spending shocks in explaining GDP forecast error variance is the lowest when the FAVAR specification is employed. As regards the UK (Figure 20b), the inclusion of exogenous controls induces both multipliers to be lower compared to the VAR model. In absolute value terms, they are smallest in the FAVAR model. Not surprisingly, the share of variance accounted for by fiscal shocks is minimized for models including global controls.

Overall, these findings may help to mitigate the "multipliers puzzle": large scale macroeconomic models (see for example the QUEST model by the European Commission, Roeger and in't Veld (2004)) generally tend to yield smaller GDP multipliers than VAR models (see Hemming, Kell and Mahfouz (2002)) for a discussion on this issue). However, we have shown that the inclusion of a richer information set in a VAR framework, as summarized by the common factors $F_{t}$, leads to a moderation in multipliers estimates. This may contribute to reconcile the empirical findings from these classes of models.

\section{Conclusions}

In this paper, we propose a "factor-augmented" VAR approach combined with identification of fiscal shocks à la Blanchard and Perotti (2002) and Perotti (2005) to study the evolution of domestic and fiscal multipliers in three OECD countries (Germany, the UK and the US), and cross-border fiscal spillovers from Germany to the seven largest European Union economies. First, a sample of thirty-four years ranging between 1971 and 2004 is analyzed. Then, re- 
cursive estimations and identifications of fiscal shocks are performed over rolling samples of 17-years. Three main conclusions can be drawn from this work.

First, domestic net tax shocks multipliers have been vanishing since the 1980s for Germany and since the 1970s in the US. This effect might be explained by financial deregulation policies, which have made households less dependent on disposable income. As for the UK, tax multipliers turn out to be small and weakly significant over the entire sample, consistent with an earlier implementation of policies promoting competitiveness in financial markets.

Secondly, when significant, cross-border multipliers generally have the same sign as domestic ones. Furthermore, fiscal spillovers, especially tax ones, are higher for small, neighboring countries than for large, remote ones. These findings suggest that the trade channel of transmission seems to dominate the interest rate one.

Finally, most cross-border multipliers fail to be relevant in subsamples including the EMU period. Importantly, they never turn negative. This is good news for the Euro area, since the reaction of German fiscal authorities to adverse macroeconomic shocks will not have a counter-productive impact on EMU countries. Symmetrically, however, these results would also imply that German fiscal adjustments to cope with the Stability and Growth Pact are very unlikely to generate positive externalities on other member countries. 


\section{References}

Ahmed, S., Levin, A. and Wilson, B. A. (2004), 'Recent U.S. Macroeconomic Stability: Good Policies, Good Practices, or Good Luck?', The Review of Economics and Statistics 86(3), 824-832.

Altissimo, F., Bassanetti, A., Cristadoro, R., Forni, M., Hallin, M., Lippi, M., Reichlin, L. and Veronese, G. (2001), Eurocoin: A Real Time Coincident Indicator of the Euro Area Business Cycle, CEPR Discussion Paper No. 3108.

Bai, J. (2003), 'Inferential Theory for Factor Models of Large Dimension', Econometrica 71(1), 135-171.

Bai, J., Lumsdaine, R. L. and Stock, J. H. (1998), 'Testing for and Dating Common Breaks in Multivariate Time Series', Review of Economic Studies 65(3), 395-432.

Bai, J. and Ng, S. (2004), 'A PANIC Attack on Unit Roots and Cointegration', Econometrica 72(4), 1127-1177.

Beetsma, R., Giuliodori, M. and Klaassen, F. (2005), Trade Spillovers of Fiscal Policy in the European Union: A Panel Analysis, CEPR Discussion Paper No. 5222.

Bénassy-Quéré, A. (2006), Short-Term Fiscal Spillovers in a Monetary Union, CEPII Working Paper No. 13.

Bernanke, B., Boivin, J. and Eliasz, P. S. (2005), 'Measuring the Effects of Monetary Policy: A Factor-augmented Vector Autoregressive (FAVAR) Approach', The Quarterly Journal of Economics 120(1), 387-422.

Bernanke, B. S. and Mihov, I. (1998), 'Measuring Monetary Policy', The Quarterly Journal of Economics 113(3), 869-902.

Blanchard, O. and Perotti, R. (2002), 'An Empirical Characterization of the Dynamic Effects of Changes in Government Spending and Taxes on Output', The Quarterly Journal of Economics 117(4), 1329-1368.

Boivin, J. and Giannoni, M. (2006), Has Monetary Policy Become More Effective?, CEPR Discussion Papers No. 5463.

Briotti, M. G. (2005), Economic Reactions to Public Finance Consolidation - a Survey of the Literature, Occasional Paper Series No. 38, European Central Bank.

Brueggemann, R. and Lütkepohl, H. (2004), A Small Monetary System for the Euro Area Based on German Data, Economics Working Paper No. 24, European University Institute.

Bryant, R. C., Henderson, D. W., Holtham, G., Hooper, P. and Symansky, S. (1988), Empirical Macroeconomics for Interdependent Economies, Washington: Brookings Insitution.

Bryant, R. C., Hooper, P. and Mann, C. L. (1993), Evaluating Policy Regimes: New Research in Empirical Macroeconomics, Washington: Brookings Insitution.

Canova, F. (2006), Monetary Policy and the Evolution of the US Economy, CEPR Discussion Paper No. 5467. 
Canzonieri, M. B., Cumby, R. E. and Diba, B. T. (2003), New Views on the Transatlantic Transmission of Fiscal Policy and Macroeconomic Policy Coordination, in 'Monetary and Fiscal Policies in EMU', Cambridge University Press, chapter 4.

Chow, G. C. (1960), 'Test of Equality Between Sets of Coefficients in Two Linear Regressions', Econometrica 28, 591-605.

Coenen, G. and Straub, R. (2005), 'Does Government Spending Crowd in Private Consumption? Theory and Empirical Evidence for the Euro Area', International Finance 8(3), 435-470.

Croux, C., Forni, M. and Reichlin, L. (2001), 'A Measure of Comovement for Economic Variables: Theory and Empirics', The Review of Economics and Statistics 83(2), 232241.

Elliott, G., Rothenberg, T. J. and Stock, J. H. (1996), 'Efficient Tests for an Autoregressive Unit root', Econometrica 64(4), 813-36.

Forni, M., Hallin, M., Lippi, M. and Reichlin, L. (2002), The Generalized Dynamic Factor Model: One-Sided Estimation and Forecasting, CEPR Discussion Paper No. 3432.

Galí, J., López-Salido, D. and Vallés, J. (2006), 'Understanding the Effects of Government Spending on Consumption', Journal of the European Economic Association (forthcoming).

Giannone, D. and Lenza, M. (2004), The Feldstein-Horioka Fact, CEPR Discussion Papers No. 4610.

Giorno, C., Richardson, P., Roseveare, D. and van den Noord, P. (1995), Estimating Potential Output, Output Gaps and Structural Budget balances, OECD Economics Department Working Paper No. 152.

Giudice, G., Turrini, A. and in't Veld, J. (2004), Non-Keynesian Fiscal Consolidation in the EU: Ex Post Evidence and Ex Ante Analysis, CEPR Discussion Paper No. 4388.

Hemming, R., Kell, M. and Mahfouz, S. (2002), The Effectiveness of Fiscal Policy in Stimulating Economic Activity - A review of the Literature, IMF Working Paper No. 208.

Lütkepohl, H. and Wolters, J. (2003), 'The Transmission of German Monetary Policy in the Pre-Euro Period', Macroeconomic Dynamics 7, 711-733.

Marcellino, M. (2006), 'Some Stylized Facts on Non-Systematic Fiscal Policy in the Euro Area', Journal of Macroeconomics 28(3), 461-479.

McKibbin, W. J. (1997), Empirical Evidence on Interational Economic Policy Coordination, in 'Handbook of Macroeconomic Policy in Open Economy', Freenwood Press, chapter 6 .

Mountford, A. and Uhlig, H. (2002), What are the Effects of Fiscal Policy Shocks?, CEPR Discussion Paper No. 3338.

Perotti, R. (2005), Estimating the Effects of Fiscal Policy in OECD Countries, CEPR Discussion Paper No. 4842. 
Primiceri, G. (2005), ‘Time Varying Structural Vector Autoregressions and Monetary Policy', The Review of Economic Studies 72, 821-852.

Reichlin, L. (2002), Factor Models in Large Cross-Sections of Time Series, CEPR Discussion Paper No. 3285.

Roeger, W. and in't Veld, J. (2004), 'Some Selected Simulation Experiments with the European Commission's QUEST Model', Economic Modelling 21, 785-832.

Shapiro, M. D. and Watson, M. W. (1988), 'Sources of Business Cycle Fluctuations', NBER Macroeconomics Annual 3, 111-156.

Stock, J. H. and Watson, M. W. (1998), Diffusion Indexes, NBER Working Paper No. 6702.

Stock, J. H. and Watson, M. W. (2003), 'Has the Business Cycle Changed?', Proceedings of the Symposium on "Monetary Policy and Uncertainty” pp. 9-56.

Van den Noord, P. (2000), The Size and the Role of Automatic Stabilizers in the 1990s and Beyond, OECD Economics Department Working Paper No. 3.

Weyerstrass, K., Jaenicke, J., Neck, R., Haber, G., van Aarle, B., Schoors, K., Gobbin, N. and Claeys, P. (2006), Economic Spillovers and Policy Coordination in the Euro Area, European Commission Economic Paper No. 246. 


\section{Appendix A: Data used for common factors' estimation.}

The data used for the estimation of common factors for non-European Union OECD countries are taken from DATASTREAM, based on OECD and IMF statistics. Variables are transformed to achieve stationarity. Data transformation codes are: 0 - no transformation; 1 - first difference; 2 - first difference of logarithm; 3 - second difference of logarithm. Data span from 1971:1 to 2004:4.

\begin{tabular}{|c|c|c|c|c|}
\hline $\mathrm{N}$. & Country & DS code & Trans. & Variable \\
\hline \multicolumn{5}{|c|}{ Private consumption } \\
\hline 1. & UNITED STATES & USOCFPCND & 2 & US PRIVATE CONSUMPTION EXPENDITURE (REAL,SA) \\
\hline 2. & CANADA & CNOCFPCND & 2 & CN PRIVATE CONSUMPTION EXPENDITURE (REAL,SA) \\
\hline 3. & MEXICO & MXOCFPCND & 2 & MX PRIVATE CONSUMPTION EXPENDITURE (REAL,SA) \\
\hline 4. & NORWAY & NWOCFPCND & 2 & NW PRIVATE CONSUMPTION EXPENDITURE (REAL,SA) \\
\hline 5. & JAPAN & JPOCFPCND & 2 & JP PRIVATE CONSUMPTION EXPENDITURE (REAL,SA) \\
\hline 6. & AUSTRALIA & AUOCFPCND & 2 & AU PRIVATE CONSUMPTION EXPENDITURE (REAL,SA) \\
\hline 7. & NEW ZEALAND & NZOCFPCND & 2 & NZ PRIVATE CONSUMPTION EXPENDITURE (REAL,SA) \\
\hline \multicolumn{5}{|r|}{ Private investment } \\
\hline 8. & UNITED STATES & USOCFPIND & 2 & US PRIV. FIXED INV. EXCL.STOCKBUILDING IN REAL TERMS (SA) \\
\hline 9. & CANADA & CNOCFPIND & 2 & CN PRIV. FIXED INV. EXCL.STOCKBUILDING IN REAL TERMS (SA) \\
\hline 10. & NORWAY & NWOCFPIND & 2 & NW PRIV. FIXED INV. EXCL.STOCKBUILDING IN REAL TERMS (SA) \\
\hline 11. & JAPAN & JPOCFPIND & 2 & JP PRIV. FIXED INV. EXCL.STOCKBUILDING IN REAL TERMS (SA) \\
\hline 12. & AUSTRALIA & AUOCFPIND & 2 & AU PRIV. FIXED INV. EXCL.STOCKBUILDING IN REAL TERMS (SA) \\
\hline 13. & NEW ZEALAND & NZOCFPIND & 2 & NZ PRIV. FIXED INV. EXCL.STOCKBUILDING IN REAL TERMS (SA) \\
\hline \multicolumn{5}{|r|}{ Industrial production } \\
\hline 14. & UNITED STATES & USQ66..CE & 2 & US INDUSTRIAL PRODUCTION (SA) \\
\hline 15. & CANADA & CNQ66..CE & 2 & CN INDUSTRIAL PRODUCTION (SA) \\
\hline 16. & NORWAY & NWQ66..CE & 2 & NW INDUSTRIAL PRODUCTION (SA) \\
\hline 17. & JAPAN & JPQ66..CE & 2 & JP INDUSTRIAL PRODUCTION (SA) \\
\hline 18. & AUSTRALIA & AUQ66..CE & 2 & $\begin{array}{l}\text { AU INDUSTRIAL PRODUCTION (SA) } \\
\text { Stocks }\end{array}$ \\
\hline 19. & UNITES STATES & USOEXP10D & 0 & US INCREASE IN STOCKS (SA) \\
\hline 20. & CANADA & CNOEXP10D & 0 & CN INCREASE IN STOCKS (SA) \\
\hline 21. & AUSTRALIA & AUOEXP10D & 0 & $\begin{array}{l}\text { AU INCREASE IN STOCKS (SA) } \\
\text { Hours }\end{array}$ \\
\hline 22. & UNITED STATES & USOCFHRBO & 2 & US AVERAGE HOURS WORKED,PER EMPLOYEE-BUS.SECTOR(SA) \\
\hline 23. & CANADA & CNOCFHRBO & 2 & CN AVERAGE HOURS WORKED,PER EMPLOYEE-BUS.SECTOR(SA) \\
\hline 24. & NORWAY & NWOCFHRBO & 2 & NW AVERAGE HOURS WORKED,PER EMPLOYEE-BUS.SECTOR(SA) \\
\hline 25. & JAPAN & JPOCFHRBO & 2 & JP AVERAGE HOURS WORKED,PER EMPLOYEE-BUS.SECTOR(SA) \\
\hline 26. & AUSTRALIA & AUOCFHRBO & 2 & AU AVERAGE HOURS WORKED,PER EMPLOYEE-BUS.SECTOR(SÁ) \\
\hline 27. & NEW ZEALAND & NZOCFHRBO & 2 & $\begin{array}{l}\text { NZ AVERAGE HOURS WORKED,PER EMPLOYEE-BUS.SECTOR(SA) } \\
\text { Unemployment }\end{array}$ \\
\hline 28. & UNITED STATES & USOCFUNRQ & 1 & US UNEMPLOYMENT RATE (SA) \\
\hline 29. & CANADA & CNOCFUNRQ & 1 & CN UNEMPLOYMENT RATE (SA) \\
\hline 30. & JAPAN & JPOCFUNRQ & 1 & JP UNEMPLOYMENT RATE (SA) \\
\hline 31. & AUSTRALIA & AUOCFUNRQ & 1 & $\begin{array}{l}\text { AU UNEMPLOYMENT RATE (SA) } \\
\text { Labor costs }\end{array}$ \\
\hline 32. & UNITED STATES & USOCFRCMG & 2 & US COMPENSATION PER EMPLOYEE (REAL,SA) \\
\hline 33. & CANADA & CNOCFRCMG & 2 & CN COMPENSATION PER EMPLOYEE (REAL,SA) \\
\hline 34. & JAPAN & JPOCFRCMG & 2 & JP COMPENSATION PER EMPLOYEE (REAL,SA) \\
\hline 35. & AUSTRALIA & AUOCFRCMG & 2 & AU COMPENSATION PER EMPLOYEE (REAL,SA) \\
\hline 36. & NEW ZEALAND & NZOCFRCMG & 2 & $\begin{array}{l}\text { NZ COMPENSATION PER EMPLOYEE (REAL,SA) } \\
\text { Government }\end{array}$ \\
\hline 37. & UNITES STATES & USOCFNL\%Q & 0 & US GOVERNMENT NET LENDING AS \% OF GDP (SA) \\
\hline 38. & CANADA & CNOCFNL\%Q & 0 & CN GOVERNMENT NET LENDING AS \% OF GDP (SA) \\
\hline 39. & JAPAN & JPOCFNL\%Q & 0 & JP GOVERNMENT NET LENDING AS \% OF GDP (SA) \\
\hline 40. & AUSTRALIA & AUOCFNL\%Q & 0 & $\begin{array}{l}\text { AU GOVERNMENT NET LENDING AS \% OF GDP (SÁ) } \\
\text { Prices }\end{array}$ \\
\hline 41. & UNITES STATES & USOCFCPIE & 3 & US CONSUMER PRICE INDEX (SA) \\
\hline 42. & CANADA & CNOCFCPIE & 3 & CN CONSUMER PRICE INDEX (SA) \\
\hline 43. & MEXICO & MXOCFCPIE & 3 & MX CONSUMER PRICE INDEX (SA) \\
\hline 44. & NORWAY & NWOCFCPIE & 3 & NW CONSUMER PRICE INDEX (SA) \\
\hline 45. & JAPAN & JPOCFCPIE & 3 & JP CONSUMER PRICE INDEX (SA) \\
\hline 46. & AUSTRALIA & AUOCFCPIE & 3 & AU CONSUMER PRICE INDEX (SA) \\
\hline 47. & NEW ZEALAND & NZOCFCPIE & 3 & $\begin{array}{l}\text { NZ CONSUMER PRICE INDEX (SA) } \\
\text { Interest rates }\end{array}$ \\
\hline 48. & UNITES STATES & USQ60B.. & 0 & $\begin{array}{l}\text { Interest rates } \\
\text { US MONEY MARKET RATE ( FEDERAL FUNDS ) }\end{array}$ \\
\hline 49. & UNITES STATES & FRTBS3M & 0 & US TREASURY BILL 2ND MARKET 3 MONTH - MIDDLE RATE \\
\hline 50. & UNITES STATES & FRTBS6M & 0 & $\begin{array}{l}\text { US TREASURY BILL 2ND MARKET } 6 \text { MONTH - MIDDLE RATE } \\
\text { Stock Prices }\end{array}$ \\
\hline 51. & UNITES STATES & DJCMP65 & 2 & DOW JONES COMPOSITE - PRICE INDEX \\
\hline
\end{tabular}




\section{Appendix B: Data description (endogenous variables)}

Some of the endogenous variables used in the VAR (US) and FAVAR (Germany and UK) models have been constructed based on quarterly series provided by the OECD Economic Outlook (No. 78, December 2005). These variables are real per capita net receipts and government spending ${ }^{32}$ (Germany, UK, US), and real per capita GDP (Germany, UK, US, France, Italy, Spain, Netherlands, Belgium, Austria). Others are taken directly from OECD original sources (OECD Economic Outlook and OECD Main Economic Indicators), without any transformation. These are GDP deflator inflation, the 10-years interest rate (Germany, UK, US), and real effective exchange rates (UK, France, Italy, Spain, Netherlands, Belgium, Austria). ${ }^{33}$

In particular, if we label with $N$ the nominal net receipts, $G$ the nominal government spending, $G D P$ the nominal gross domestic product, $D E F L$ the GDP deflator, $C P I$ the consumer price index, $P O P$ the total population; the variables used in the single country and two country models are defined as follows ("code" refers to the taxonomy used in the OECD Economic Outlook Database Inventory):

- $n$ : real per capita net receipts.

$$
n=\frac{N}{P O P \times D E F L}
$$

where,

$\circ N=$ current receipts (code $: Y R G$ ) - current transfers by the government;

$\circ Y R G=$ direct taxes $($ code $: T Y)+$ indirect taxes $($ code $: T I N D)$;

$\circ$ Direct taxes $=$ direct taxes on business received by the government $($ code $: T F Y B$ ) + direct taxes on households received by the government (code : TFYH);

$\circ$ Current transfers by the government $=$ subsidies $($ code $: T S U B)+$ social security benefits paid by the government (code : $S S P G$ ).

- $g$ : real per capita government spending.

$$
g=\frac{G}{P O P \times D E F L}
$$

where,

$\circ G=$ government final consumption expenditure (code : $C G)+$ government fixed capital formation (code : $I G$ ).

\footnotetext{
${ }^{32}$ General government data have been used, i.e. they include central governments, social security and local governments.)

${ }^{33}$ Note that German data for the pre-1991:1 period refer to Western Germany only.
} 
- $y$ : real per capita GDP.

$$
y=\frac{G D P}{P O P \times D E F L}
$$

- $p$ : GDP deflator inflation.

$$
p_{t}=\frac{\left(D E F L_{t}-D E F L_{(t-4)}\right) \times 100}{D E F L_{(t-4)}}
$$

- $i$ : 10-years interest rate on government bonds (code : IRL).

- er: real effective exchange rate (volume) (code : EXCHER).

\section{Appendix C: Construction of output and price elasticities of net taxes ${ }^{34}$}

The construction of elasticities is conceptually identical to what proposed by Perotti (2005), based on the works by Giorno, Richardson, Roseveare and van den Noord (1995) and Van den Noord (2000). The only notable differences are that we use country-specific output elasticities of indirect taxes instead of assuming them homogeneously equal to one. Moreover, we compute directly output elasticities of transfers without fixing them to -0.2 for all countries. Then, any possible difference between estimates of elasticities in this work and those in Perotti (2005) may arise only due to these (minor) discrepancies or, more importantly, to the estimation sample used (and, for the case of Germany, to the inclusion of the post-unification). In particular,

\section{Construction of $\alpha_{n y}$}

Recalling that the net tax variable is derived by subtracting transfers from current receipts (see equation (B.1) in Appendix B), the elasticties of each component in these two aggregates are computed and then averaged taking into consideration their relative weights. Notably:

- Output elasticities of income taxes on households and social securities contributions are computed following equations (B.1) to (B.3) in Perotti (2005);

- Output elasticity of indirect taxes is fixed at $0.95,1.10$ and 0.94 for Germany, the UK and the US respectively (see Van den Noord (2000) Table A.9);

- Output elasticities of corporate income taxes is set equal to zero for Germany and the UK, since in these two countries tax collection lags seem to be important. For the US, instead, we regress $\log$ corporate profits on lags 0 to 4 of $\log$ GDP and we use the estimated coefficient at lag zero as a proxy for the elasticity;

\footnotetext{
${ }^{34}$ Matlab codes are available from the authors.
} 
- Output elasticities of subsidies and social security benefits, excluding unemployment benefits, are set equal to zero since there is no reasons assume that they respond automatically to changes in output. On the contrary, unemployment benefits are assumed to respond fully to output fluctuations within the same quarter. Output elasticities of transfer are then derived by aggregating these two terms (zero and one), after weighting them for their relative importance.

The weighted average of these "item-specific" elasticities gives a value for $\alpha_{n y}$ of 1.38 for Germany, 1.33 for the UK and 1.41 for the US.

\section{Construction of $\alpha_{n p}$}

- Price elasticities of income taxes on households and social security contributions are obtained from the OECD (Van den Noord (2000));

- Price elasticities of corporate income taxes and indirect taxes are set equal to zero;

- Price elasticities of transfers are set equal to -1 since, although social expenditures are often indexed to inflation, revisions generally do not occur within the same quarter.

Final estimates of $\alpha_{n p}$ are based on weighted averages of these elasticities. In particular, we get $1.05,0.93$ and 1.16 for Germany, the UK and the US respectively. 
Table 1: Augmented Dickey Fuller (ADF) and Elliott, Rothenberg and Stock (ERS) unit root tests. Sample: 1971:1 - 2004:4.

\begin{tabular}{lcccc} 
Variable & \multicolumn{2}{c}{ Germany } & United Kingdom & United States \\
\hline \hline & ADF & ERS & ADF & ADF \\
\cline { 2 - 5 } & & & & \\
Net Taxes & -2.40 & -0.50 & -2.50 & -3.33 \\
Gov. Spending & -2.76 & -1.77 & -0.45 & -1.54 \\
GDP & -2.31 & -1.70 & -1.45 & -2.72 \\
Inflation & -2.63 & -0.97 & -3.27 & -2.84 \\
Interest rate & -3.46 & -0.75 & -4.29 & -2.41 \\
\hline \hline
\end{tabular}

Note: The ADF and ERS tests include four lags of the dependent variable, a constant and a linear trend.

$\begin{array}{ccc}\text { ADF test critical values } & \text { 1\% level: } & -4.02 \\ & 5 \% \text { level: } & -3.44 \\ & 10 \% \text { level: } & -3.14 \\ \text { ERS test critical values }^{a} & 1 \% \text { level: } & -3.58 \\ & 5 \% \text { level: } & -3.03 \\ & 10 \% \text { level: } & -2.74\end{array}$

${ }^{a}$ See Elliott et al. (1996), Table I.C, T=100. 


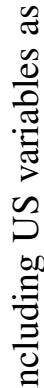

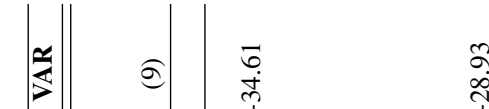

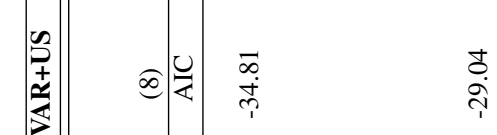

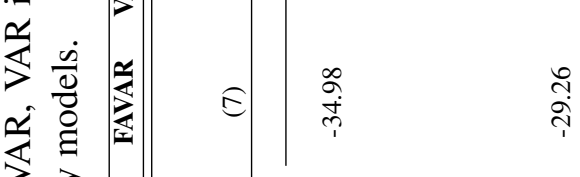

空芯

\section{ब ๙}

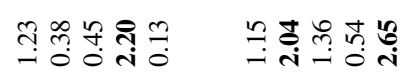

$=\sqrt{3}$

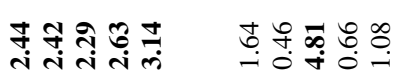

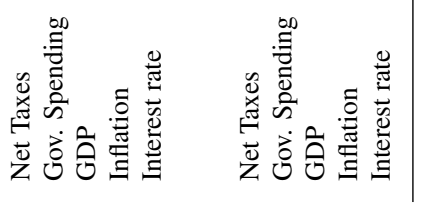
证

$\ddot{i} \dot{\theta}$

常 


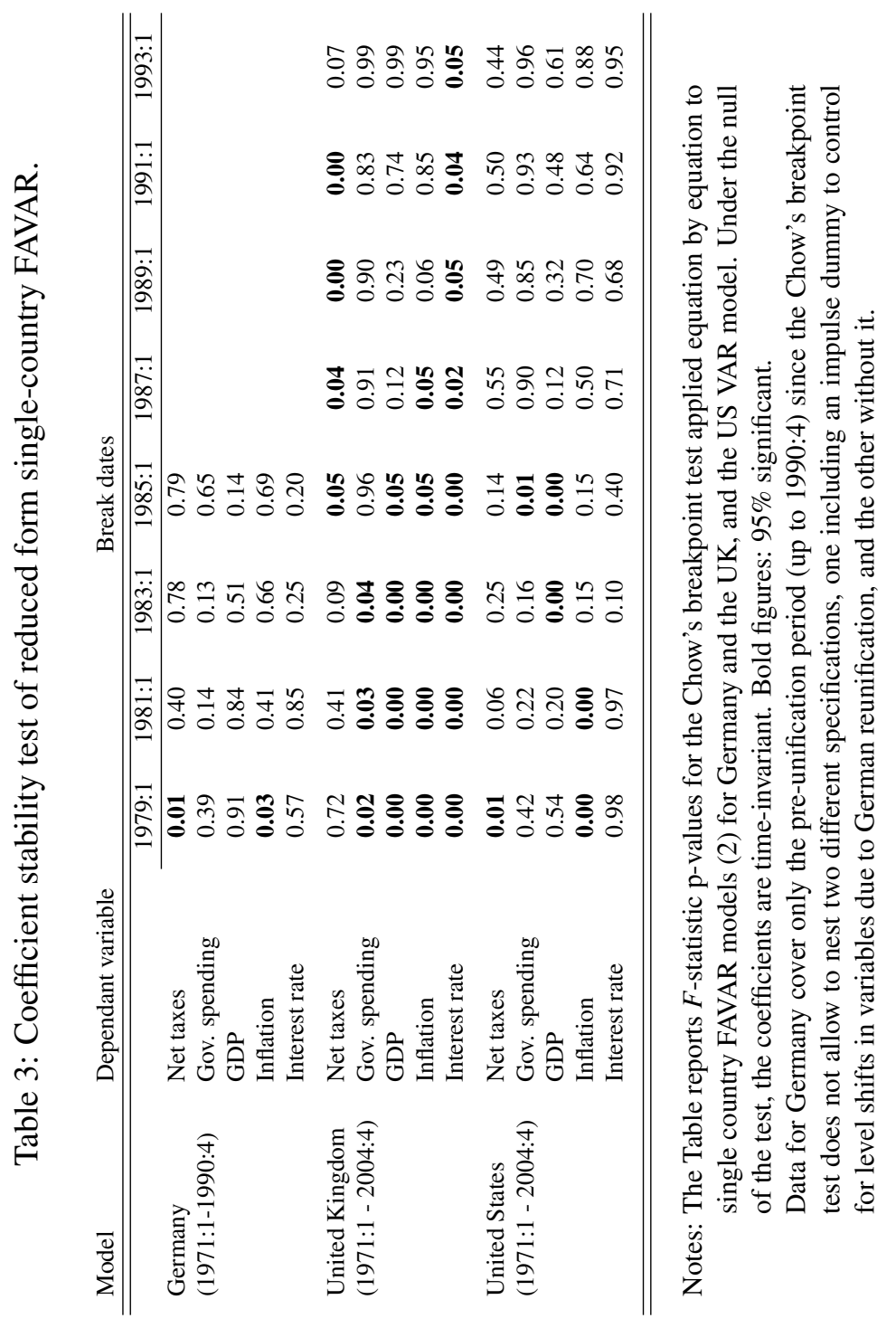


Table 4: Robustness Checks: domestic and cross-border GDP multipliers.

\begin{tabular}{|c|c|c|c|c|c|c|c|c|c|c|c|}
\hline & & \multicolumn{2}{|c|}{ Baseline $^{a}$} & \multicolumn{2}{|c|}{$\mathbf{k}=\mathbf{1}^{b}$} & \multicolumn{2}{|c|}{ Levels $^{c}$} & \multicolumn{2}{|c|}{ Perotti el. $^{d}$} & \multicolumn{2}{|c|}{$\mathbf{R}=\mathbf{1}^{e}$} \\
\hline & & $1 \mathrm{q}$ & $8 \mathrm{q}$ & $1 \mathrm{q}$ & $8 \mathrm{q}$ & $1 \mathrm{q}$ & $8 \mathrm{q}$ & $1 \mathrm{q}$ & $8 \mathrm{q}$ & $1 \mathrm{q}$ & $8 \mathrm{q}$ \\
\hline & & (1) & (2) & (3) & (4) & (5) & (6) & (7) & (8) & (9) & (10) \\
\hline \multicolumn{12}{|c|}{ Single country models } \\
\hline & shock & & & & & & & & & & \\
\hline \multirow{2}{*}{ Germany } & $n$ & 1.17 & 1.08 & 0.95 & 0.51 & 1.10 & 0.10 & 0.96 & 0.92 & 1.11 & 1.26 \\
\hline & $g$ & 0.23 & -0.23 & 0.19 & 0.02 & 0.21 & 0.24 & 0.39 & -0.08 & 0.41 & 0.15 \\
\hline \multirow{2}{*}{ U.K. } & $n$ & 0.23 & 0.07 & 0.28 & 0.35 & 0.24 & 0.10 & 0.01 & -0.13 & 0.24 & 0.16 \\
\hline & $g$ & 0.12 & -0.30 & 0.10 & 0.16 & 0.21 & 0.24 & 0.16 & -0.27 & 0.06 & -0.61 \\
\hline \multirow{2}{*}{ U.S. } & $n$ & -0.07 & 0.53 & -0.14 & -0.19 & -0.17 & -0.05 & 0.10 & 0.76 & & \\
\hline & $g$ & 1.07 & 0.26 & 0.85 & 0.58 & 1.08 & 1.28 & 1.12 & 0.28 & & \\
\hline \multicolumn{12}{|c|}{ Two-country models } \\
\hline \multirow{2}{*}{ France } & $n$ & 0.33 & 0.23 & 0.14 & 0.05 & 0.15 & 0.33 & 0.30 & 0.23 & 0.30 & 0.68 \\
\hline & $g$ & -0.12 & -1.10 & -0.10 & -0.23 & -0.28 & -0.37 & -0.09 & -1.07 & 0.01 & -0.17 \\
\hline \multirow{2}{*}{ U.K. } & $n$ & 0.50 & 0.16 & 0.36 & 0.28 & 0.28 & 0.77 & 0.46 & 0.13 & 0.51 & 0.14 \\
\hline & $g$ & 0.19 & -0.24 & -0.38 & -0.49 & -0.80 & -0.69 & 0.26 & -0.22 & 0.24 & -0.41 \\
\hline \multirow{2}{*}{ Italy } & $n$ & 0.13 & 0.35 & 0.06 & -0.07 & -0.07 & 0.23 & 0.12 & 0.24 & 0.08 & 0.58 \\
\hline & $g$ & 0.39 & 0.51 & 0.19 & 0.27 & 0.52 & 0.19 & 0.40 & 0.58 & 0.53 & 0.97 \\
\hline \multirow{2}{*}{ Spain } & $n$ & -0.27 & -0.35 & -0.47 & -0.13 & -0.45 & -0.62 & -0.43 & -0.68 & -0.26 & -0.16 \\
\hline & $g$ & -0.13 & -1.98 & 0.17 & -0.26 & -0.21 & -1.41 & -0.12 & -1.92 & -0.09 & -1.47 \\
\hline \multirow{2}{*}{ Netherlands } & $n$ & 0.55 & 0.32 & 0.46 & 0.42 & 0.50 & 0.31 & 0.41 & 0.17 & 0.49 & 0.52 \\
\hline & $g$ & 0.36 & 0.05 & 0.36 & 0.02 & 0.36 & -0.81 & 0.44 & 0.12 & 0.61 & 0.77 \\
\hline \multirow{2}{*}{ Belgium } & $n$ & 0.12 & 0.10 & 0.05 & -0.18 & 0.08 & 0.22 & 0.04 & 0.01 & 0.13 & 0.81 \\
\hline & $g$ & 0.32 & 0.01 & 0.20 & -0.21 & -0.09 & -0.63 & 0.34 & 0.03 & 0.46 & 1.53 \\
\hline \multirow{2}{*}{ Austria } & $n$ & 0.21 & 0.23 & 0.08 & -0.27 & 0.04 & 0.40 & 0.00 & 0.05 & 0.18 & 0.55 \\
\hline & $g$ & 0.30 & -0.67 & 0.06 & -0.03 & 0.06 & -0.84 & 0.36 & -0.59 & 0.50 & 0.24 \\
\hline
\end{tabular}

Notes: The top part of the table (single country models) reports domestic one-quarter and eight quarter GDP multipliers to net taxes $(n)$ and government spending $(g)$ shocks equal to one percent of domestic GDP. The bottom part (two-country models) displays cross-border GDP multipliers to German $(n)$ and $(g)$ shocks equal to one percent of German GDP. Five different specifications of the model are considered (bold indicates $90 \%$ significance):

$a$. The baseline single country model is (2), where three factors are used for Germany and the UK, and without the inclusion of any factor for the US. The baseline two country model is (3), which include three common factors.

$b$. Number of lags $(k)=1$.

c. Models estimated with variables in levels. In the German and UK FAVAR three nonstationary common factors have included as controls. They are estimated first by computing static principal components on the panel of variables listed in Appendix B, properly transformed to achieve stationarity. Then, the static factors are cumulated over time as suggested by Bai and $\mathrm{Ng}$ (2004).

$d$. Elasticities estimated by Perotti (2005) (over a partially different data sample) are used. In particular, $\alpha_{n y}$ and $\alpha_{n p}$ are set equal to $0.92,0.76,1.85$ and $0.87,1.21,1.25$ for Germany, the UK and the US respectively. $\alpha_{g p}$ is unchanged at -0.5 since this is the same value used by Perotti.

$e$. One factor only is included as regressor in FAVARs (2) for Germany and the UK. 

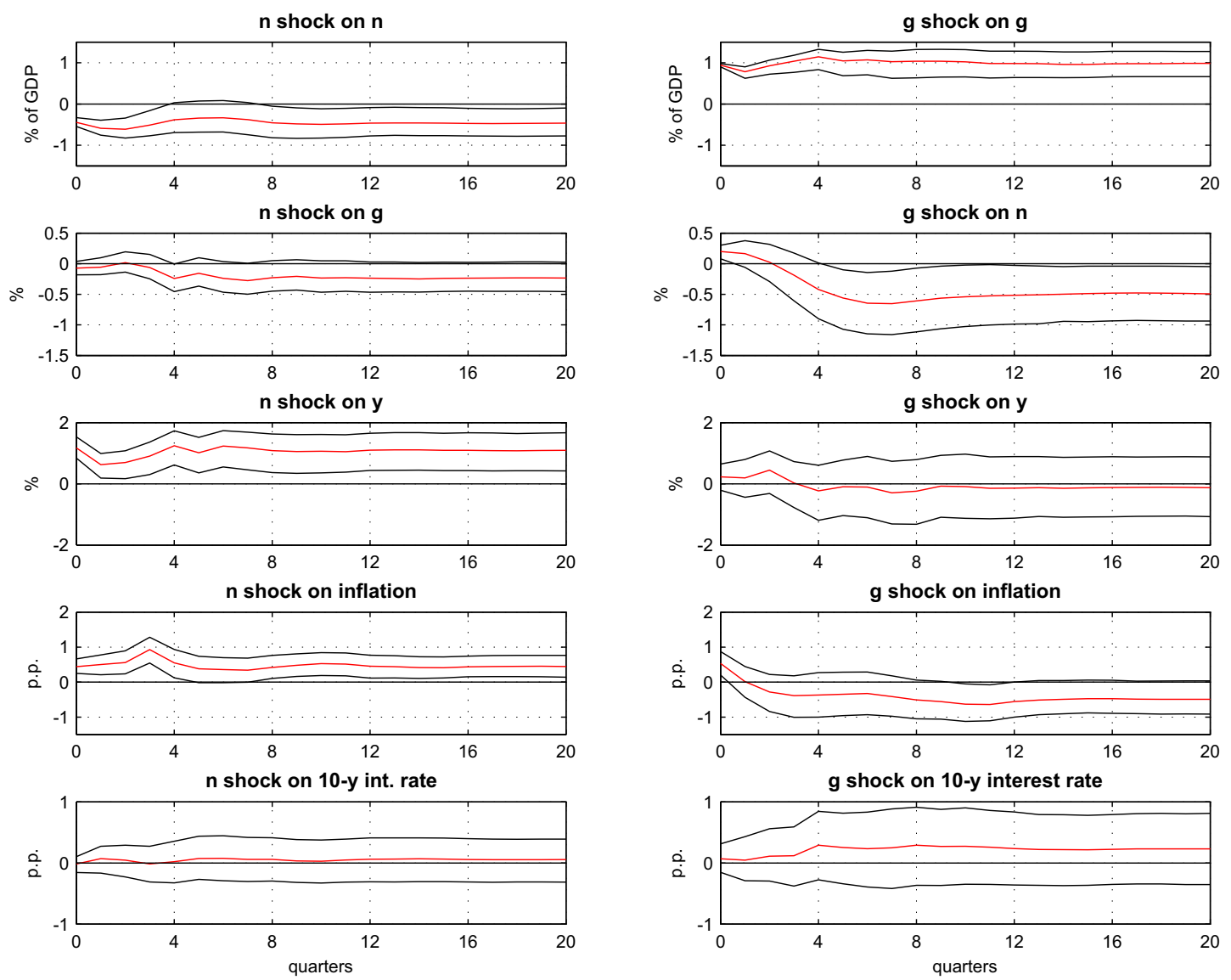

Figure 1: Germany. Effects of a shock to real per capita net receipts $(n)$ and government spending $(g)$ equal to one percent of German GDP on $n, g$, real per capita GDP $(y)$, inflation and nominal interest rate on 10-years government bonds. Red lines: baseline impulse responses. Dark lines: 90\% confidence bands based on 1000 bootstrap replications. Sample: 1971:1 - 2004:4. 

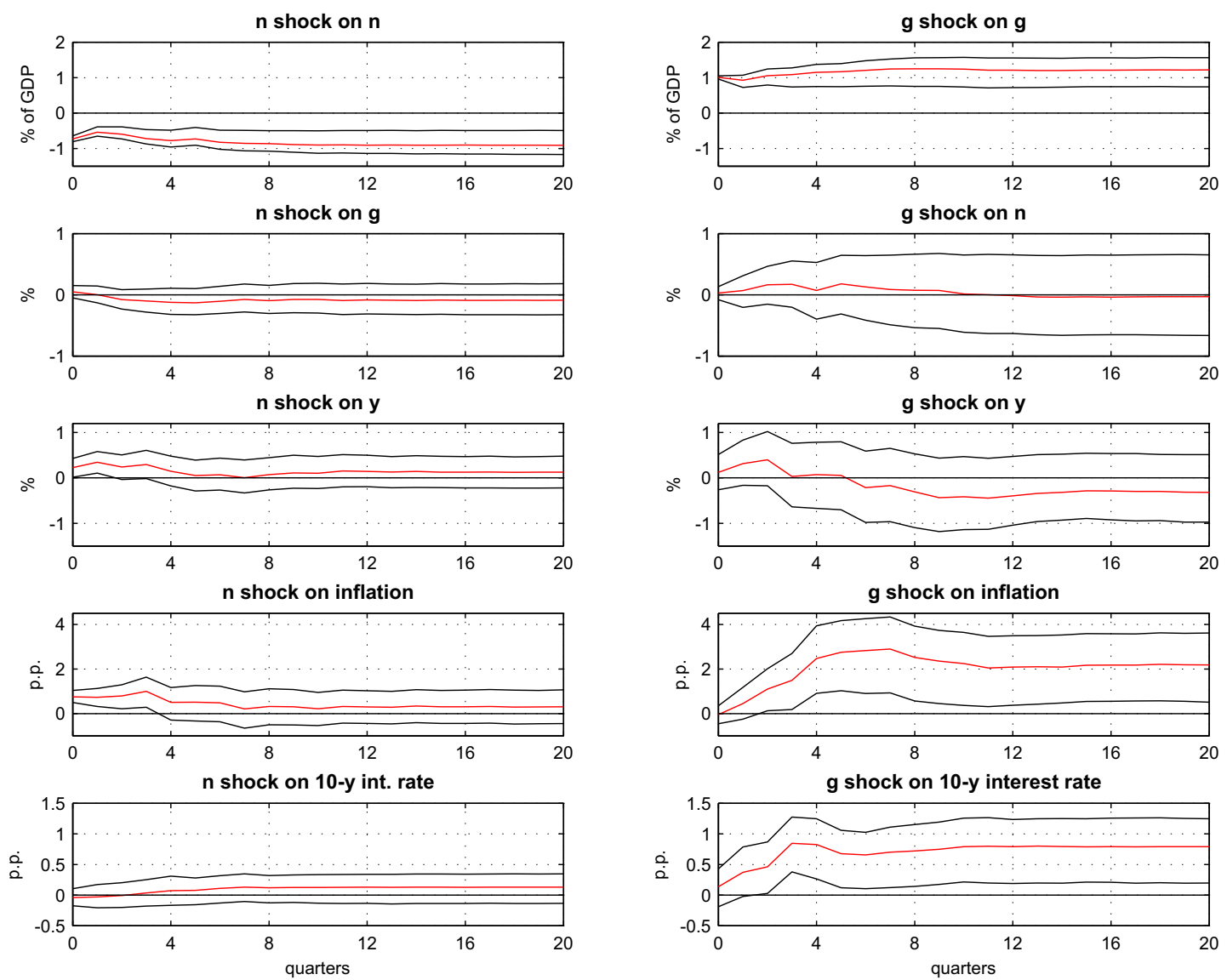

Figure 2: United Kingdom. Effects of a shock to real per capita net receipts $(n)$ and government spending $(g)$ equal to one percent of UK GDP on $n, g$, real per capita GDP $(y)$, inflation and nominal interest rate on 10-years government bonds. Red lines: baseline impulse responses. Dark lines: 90\% confidence bands based on 1000 bootstrap replications. Sample: 1971:1 - 2004:4. 

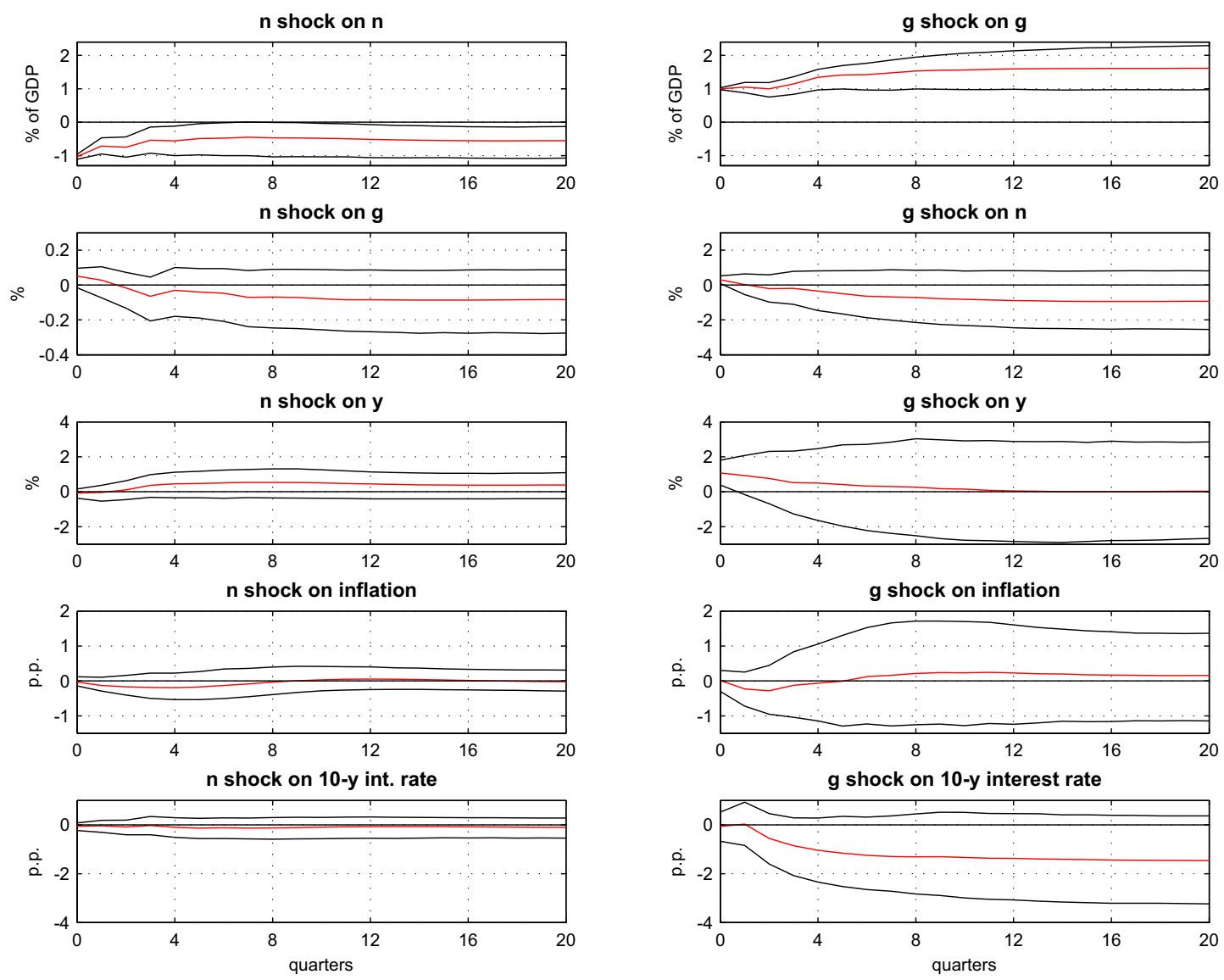

Figure 3: United States. Effects of a shock to real per capita net receipts $(n)$ and government spending $(g)$ equal to one percent of US GDP on $n, g$, real per capita GDP $(y)$, inflation and nominal interest rate on 10-years government bonds. Red lines: baseline impulse responses. Dark lines: 90\% confidence bands based on 1000 bootstrap replications. Sample: 1971:1 - 2004:4. 
CEPII, Working Paper No 2006-24

Figure 4a: Effects of German net tax shocks on German GDP over different samples.

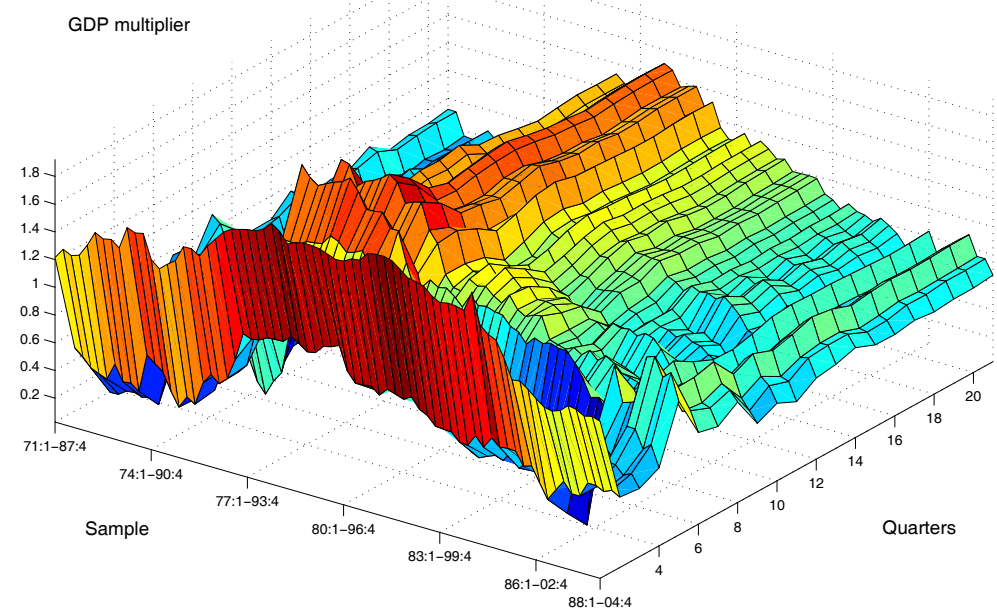

Figure 4b: Effects of German gov. spending shocks on German GDP over different samples.

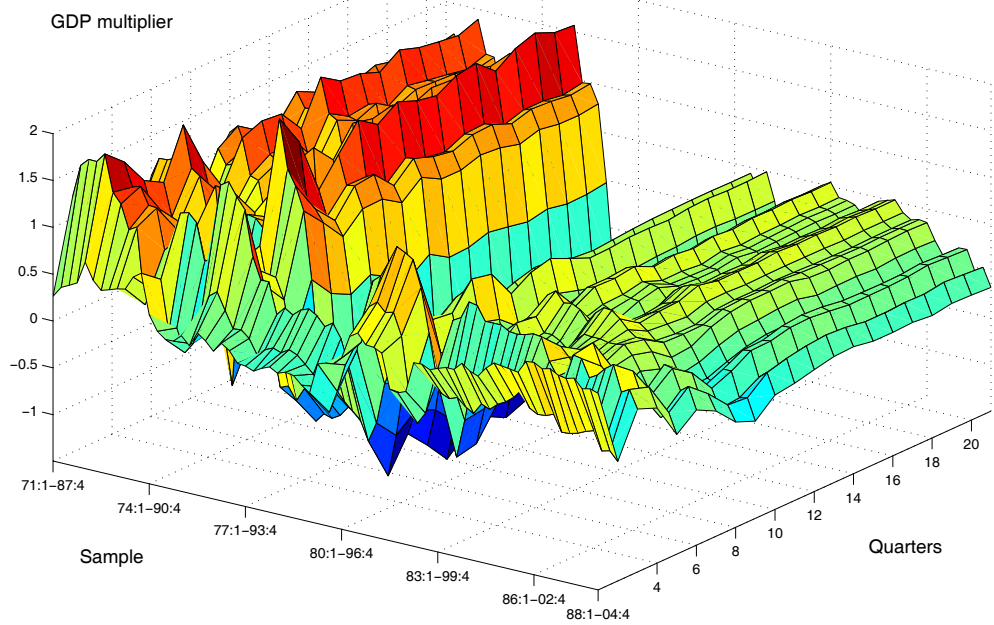

Figure 4: Germany. Recursive estimate of impulse response functions over 17-years rolling samples of data. Percentage response of domestic GDP to a domestic negative tax shock (Figure 4a) and domestic positive government spending shock (Figure $4 \mathrm{~b}$ ) equal to one percent of GDP. 
Figure 5a: Effects of UK net tax shocks on UK GDP over different samples.

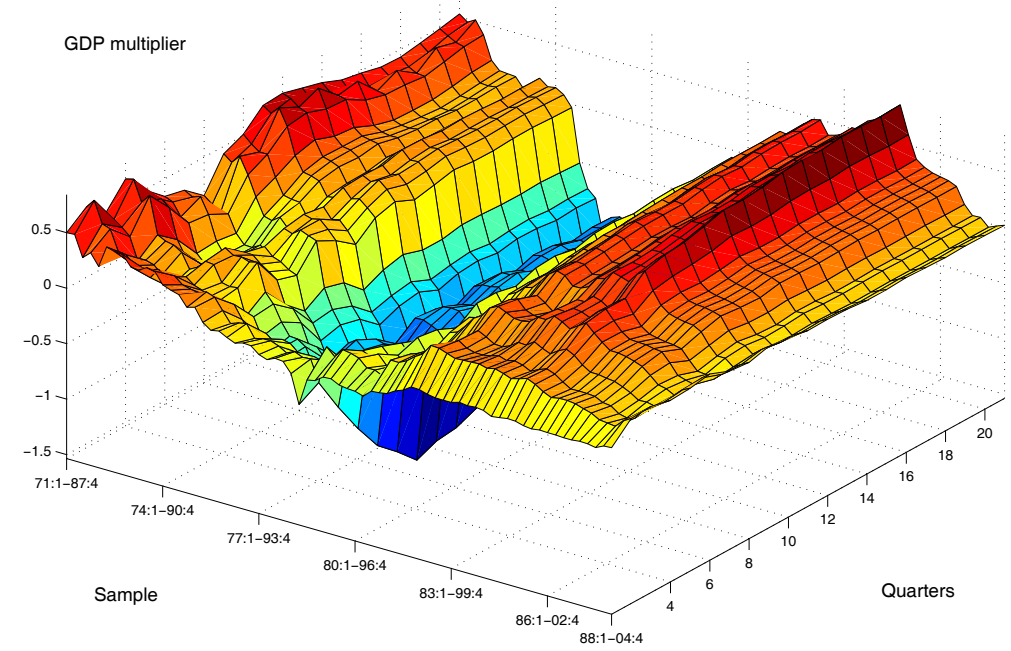

Figure 5b: Effects of UK gov. spending shocks on UK GDP over different samples.

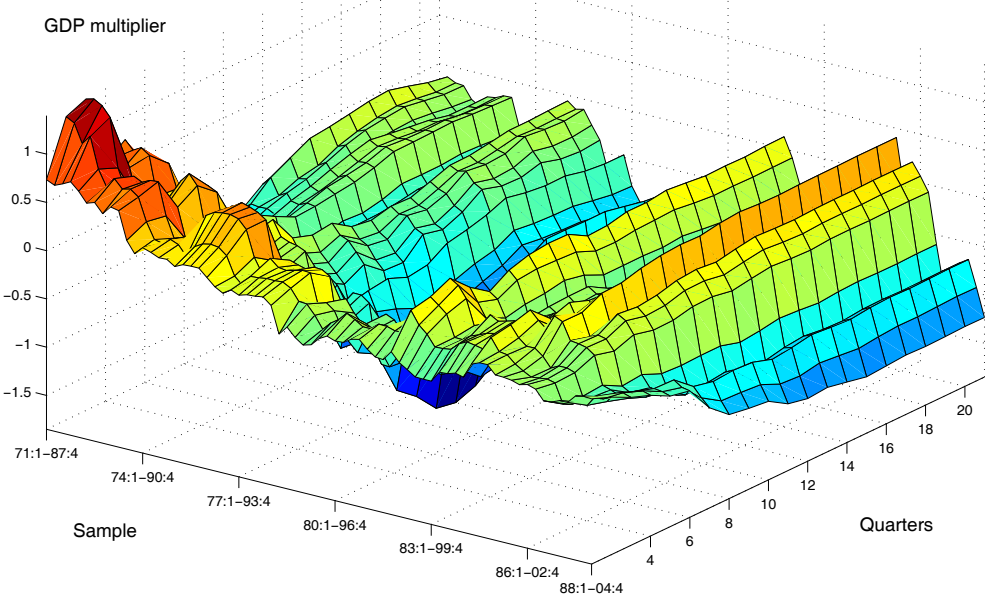

Figure 5: United Kingdom. Recursive estimate of impulse response functions over 17-years rolling samples of data. Percentage response of domestic GDP to a domestic negative tax shock (Figure 4a) and domestic positive government spending shock (Figure $4 \mathrm{~b}$ ) equal to one percent of GDP. 
Figure 6a: Effects of US net tax shocks on US GDP over different samples.

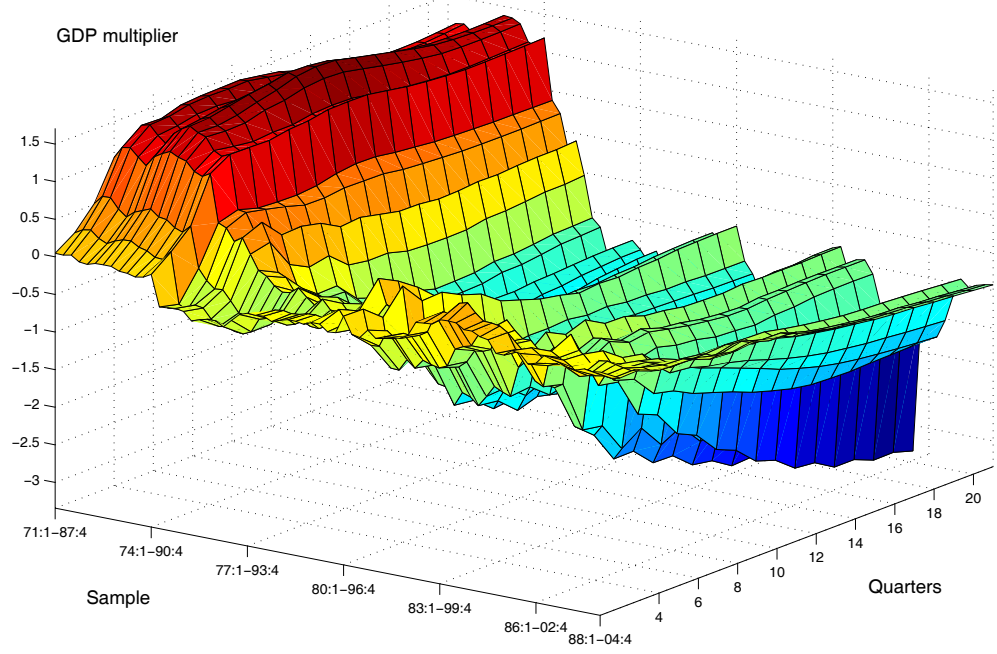

Figure 6b: Effects of US gov. spending shocks on US GDP over different samples.

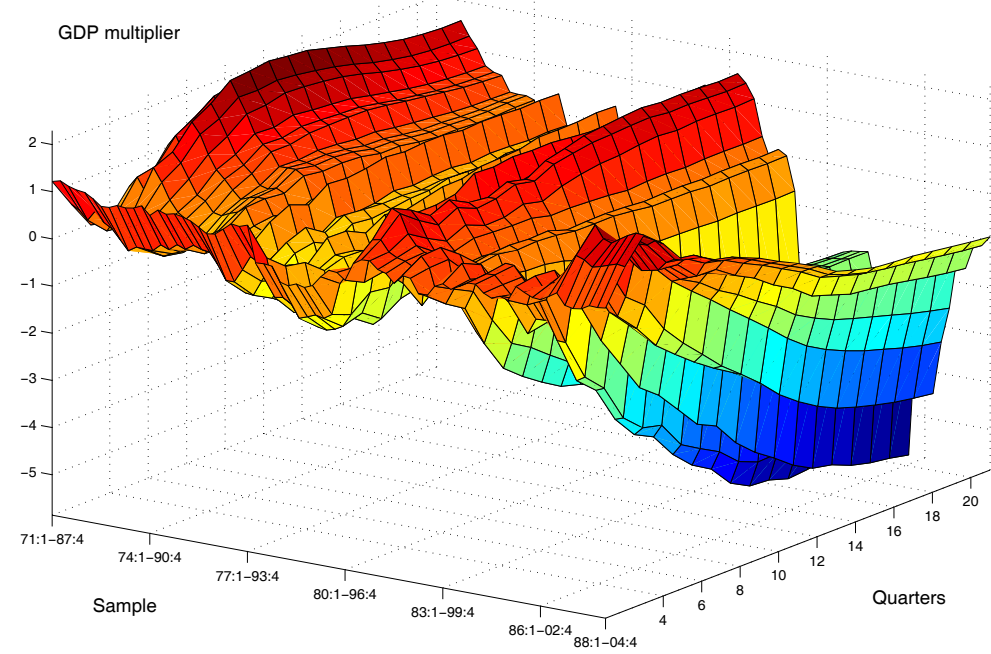

Figure 6: United States. Recursive estimate of impulse response functions over 17years rolling samples of data. Percentage response of domestic GDP to a domestic negative tax shock (Figure $4 \mathrm{a}$ ) and domestic positive government spending shock (Figure $4 b$ ) equal to one percent of GDP. 
Changing Patterns of Fiscal Policy Multipliers in Europe and the US

Figure 7a: German net taxes shock
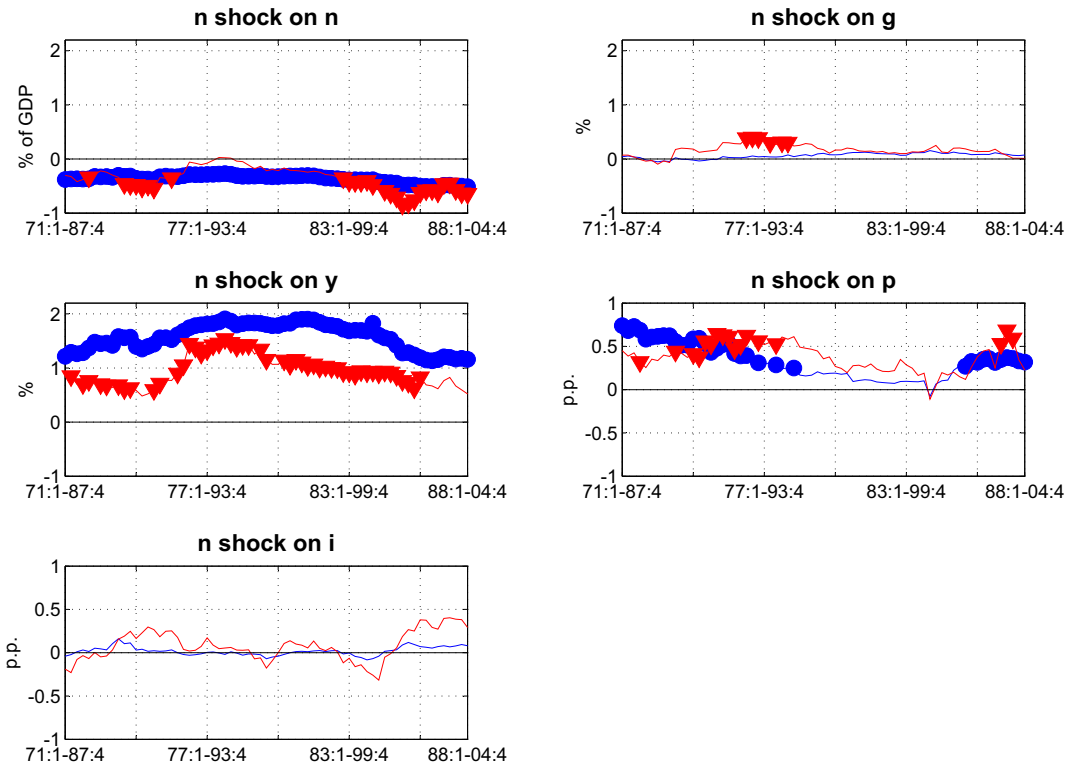

Figure 7b: German gov. spending shock

g shock on $\mathbf{n}$
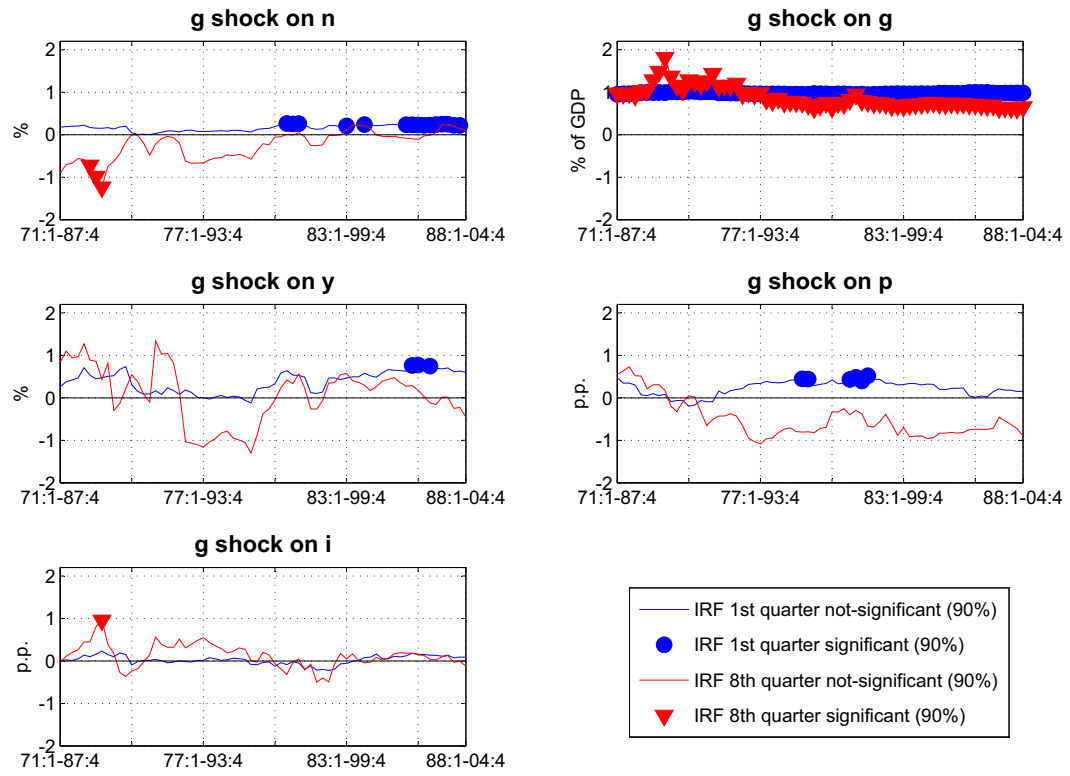

$$
\begin{aligned}
& \text { IRF 1st quarter not-significant (90\%) } \\
& \text { IRF 1st quarter significant (90\%) } \\
& \text { IRF 8th quarter not-significant (90\%) } \\
& \text { IRF 8th quarter significant (90\%) }
\end{aligned}
$$

Figure 7: Germany. Recursive estimate of impulse response functions over 17-years rolling samples of data. Effects of net taxes shocks (Figure 7a) and government spending shocks (Figure 7b) equal to one percent of domestic GDP. Blue lines are short-term multipliers (one quarter IRFs), red lines the two years multipliers (8 quarters IRFs). Markers indicate $90 \%$ significance over the corresponding data window. 
Figure 8a: UK net taxes shock
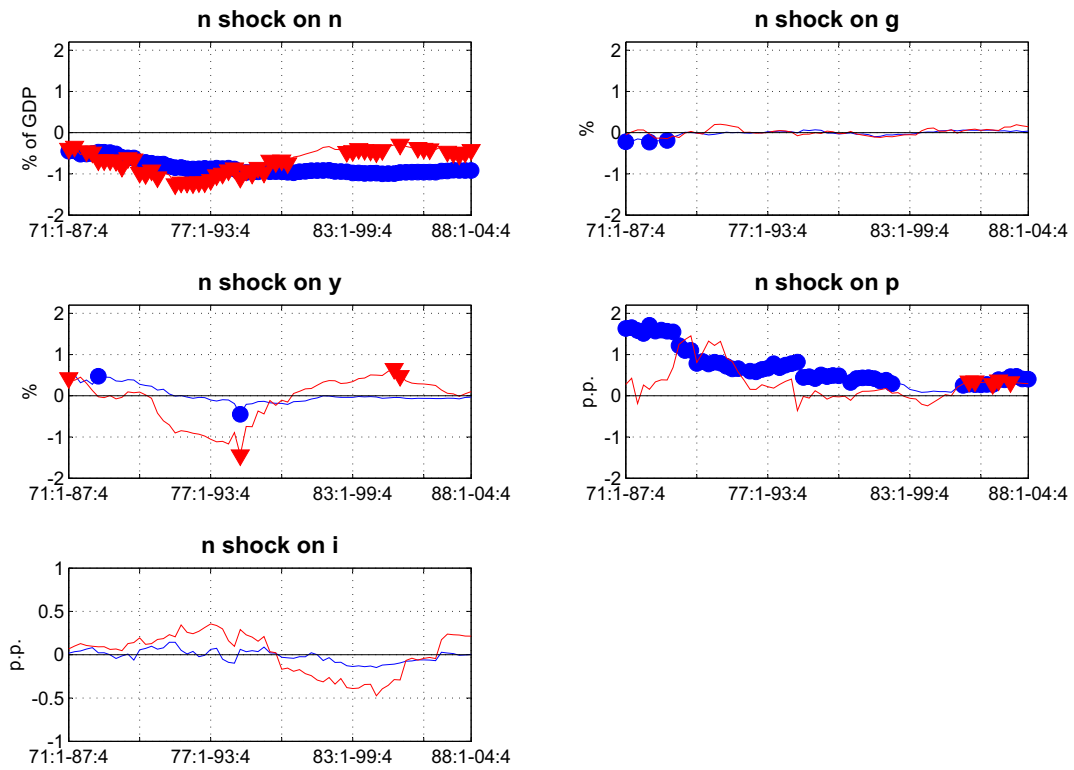

Figure 8b: UK gov. spending shock
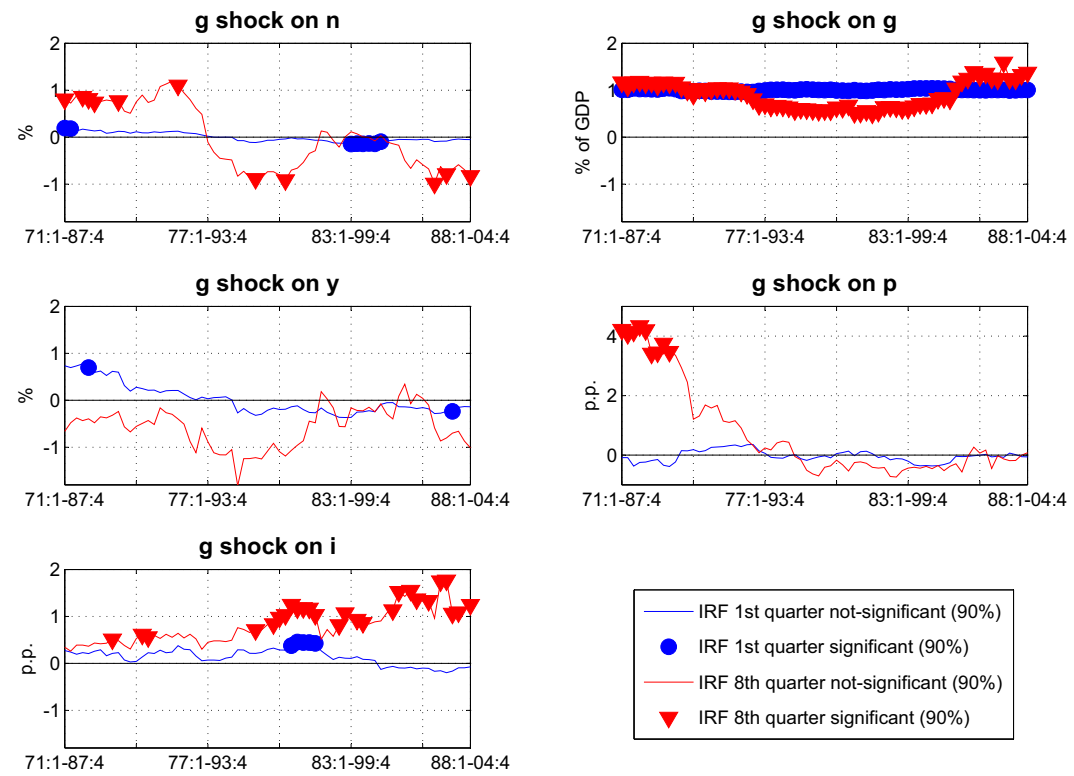

$$
\begin{aligned}
& \text { IRF 1st quarter not-significant (90\%) } \\
& \text { IRF 1st quarter significant (90\%) } \\
& \text { IRF 8th quarter not-significant (90\%) } \\
& \text { IRF 8th quarter significant }(90 \%)
\end{aligned}
$$

Figure 8: United Kingdom. Recursive estimate of impulse response functions over 17-years rolling samples of data. Effects of net taxes shocks (Figure 8a) and government spending shocks (Figure $8 b$ ) equal to one percent of domestic GDP. Blue lines are short-term multipliers (one quarter IRFs), red lines the two years multipliers (8 quarters IRFs). Markers indicate $90 \%$ significance over the corresponding data window. 
Changing Patterns of Fiscal Policy Multipliers in Europe and the US

Figure 9a: US net taxes shock
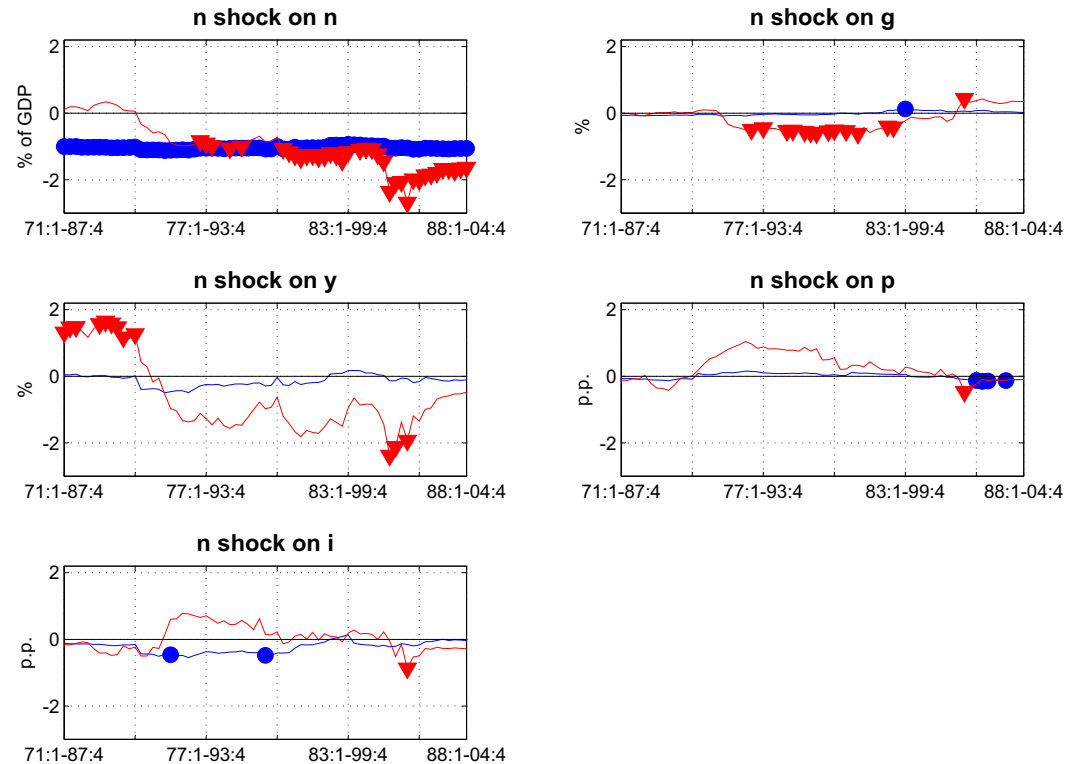

Figure 9b: US gov. spending shock
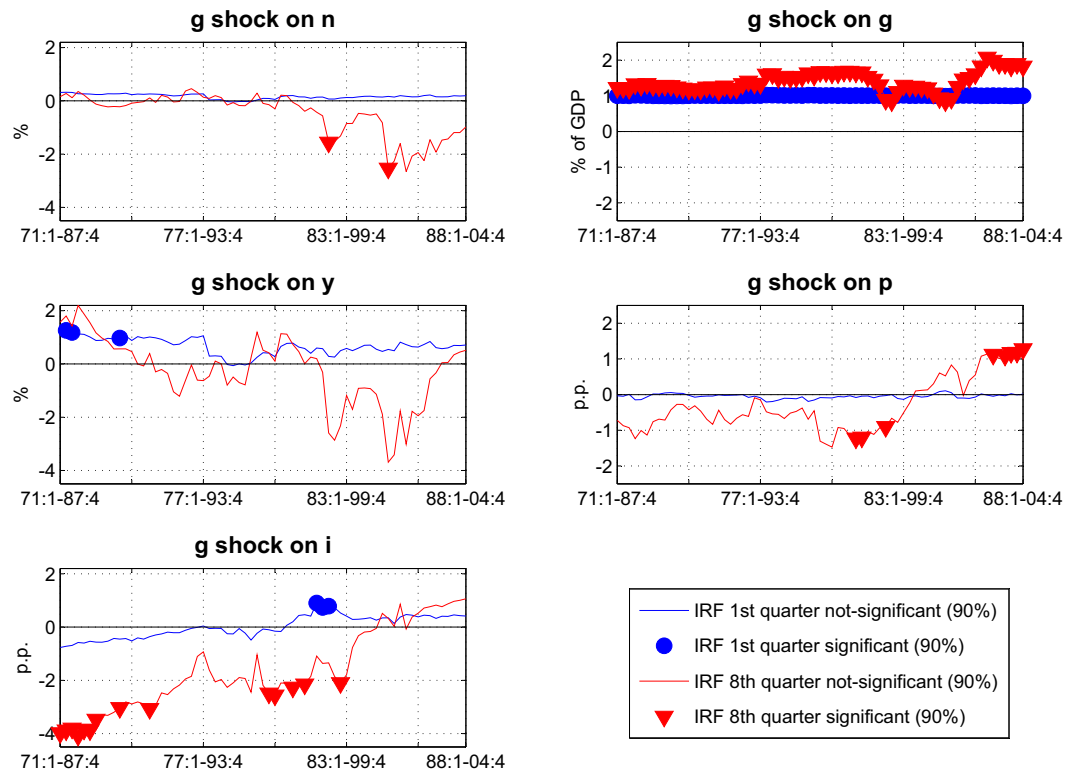

$$
\begin{aligned}
& \text { IRF 1st quarter not-significant (90\%) } \\
& \text { IRF 1st quarter significant (90\%) } \\
& \text { IRF 8th quarter not-significant (90\%) } \\
& \text { IRF 8th quarter significant }(90 \%)
\end{aligned}
$$

Figure 9: United States. Recursive estimate of impulse response functions over 17years rolling samples of data. Effects of net taxes shocks (Figure 9a) and government spending shocks (Figure 9b) equal to one percent of domestic GDP. Blue lines are short-term multipliers (one quarter IRFs), red lines the two years multipliers (8 quarters IRFs). Markers indicate $90 \%$ significance over the corresponding data window. 
Figure 10a: GDP variance due to net tax shocks

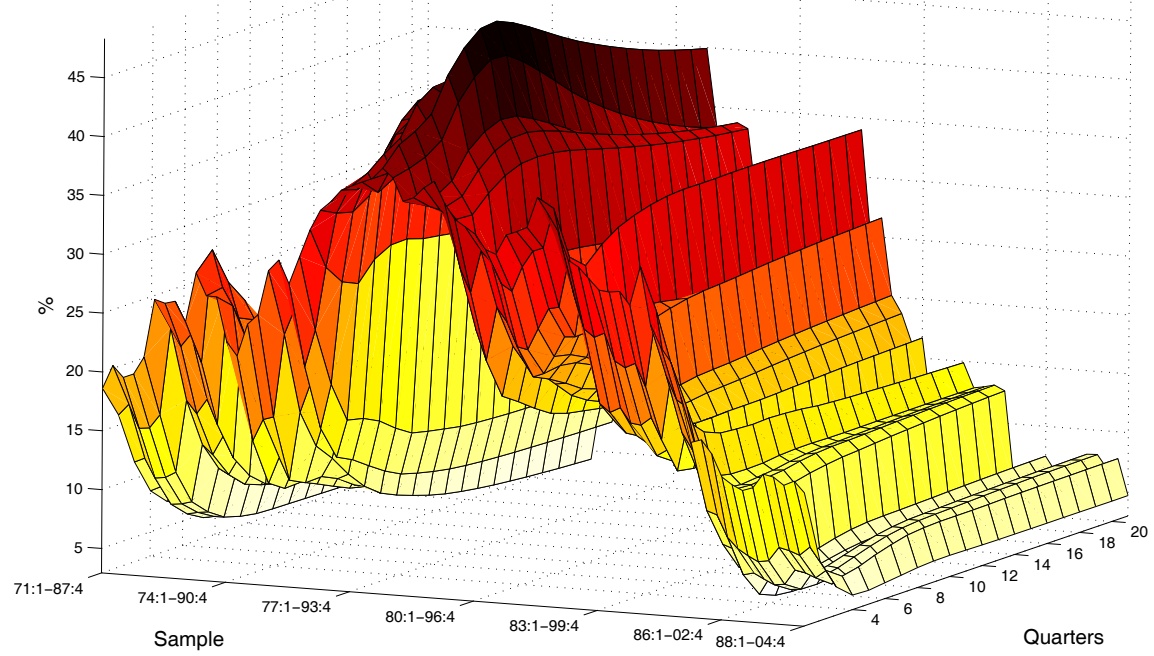

Figure 10b: GDP variance due to government spending shocks

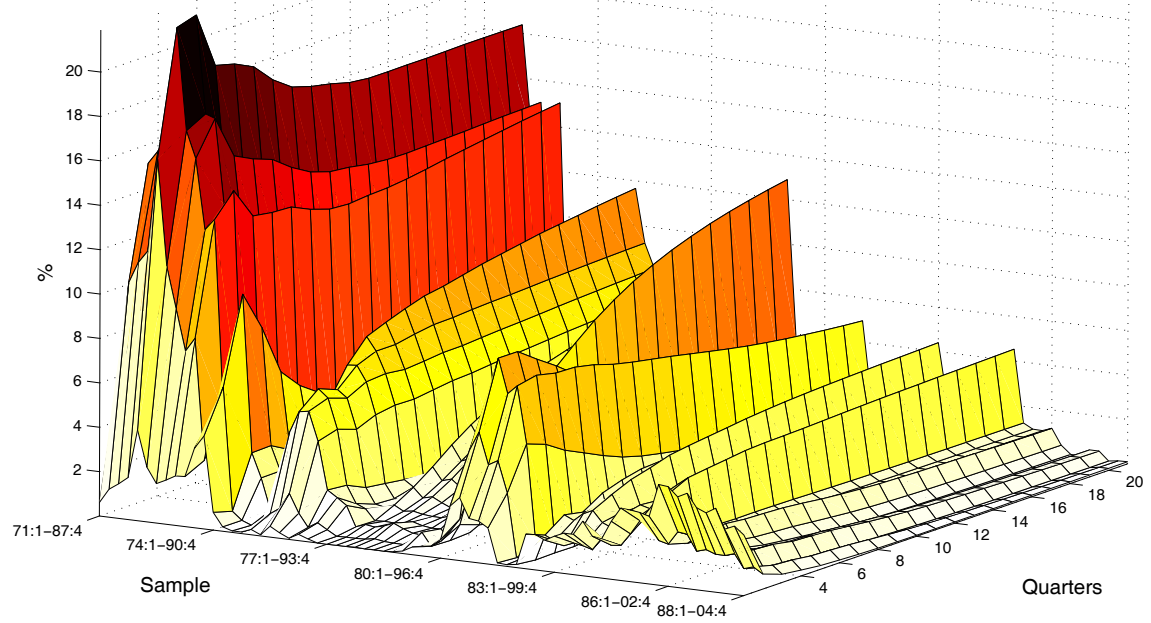

Figure 10: Germany. Forecast error variance decomposition. Percentage of GDP variance explained by net tax shocks (Figure 10a) and government spending shocks (Figure 10b) over different horizons and data samples. 
Changing Patterns of Fiscal Policy Multipliers in Europe and the US

Figure 11a: GDP variance due to net tax shocks

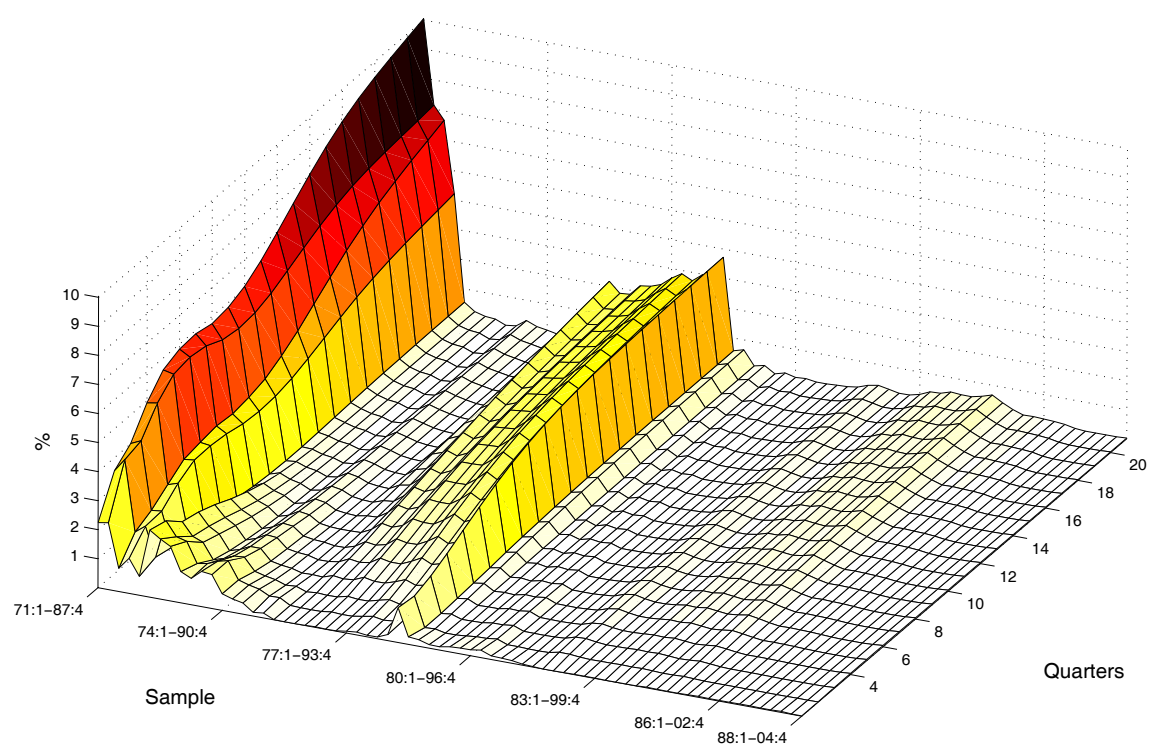

Figure 11b: GDP variance due to government spending shocks

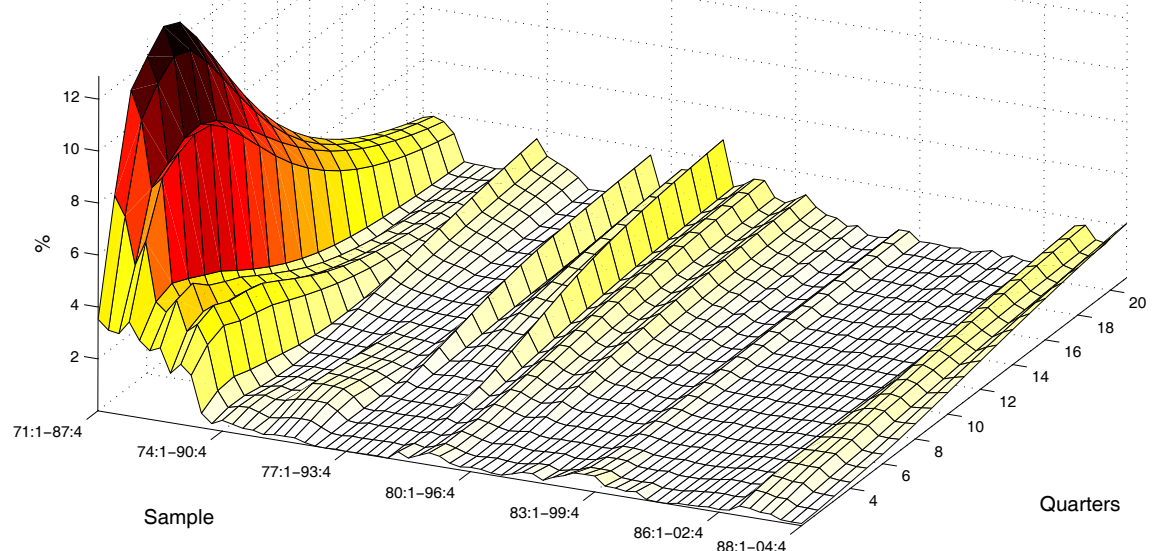

Figure 11: United Kingdom. Forecast error variance decomposition. Percentage of GDP variance explained by net tax shocks (Figure 11a) and government spending shocks (Figure 11b) over different horizons and data samples. 
Figure 12a: GDP variance due to net tax shocks

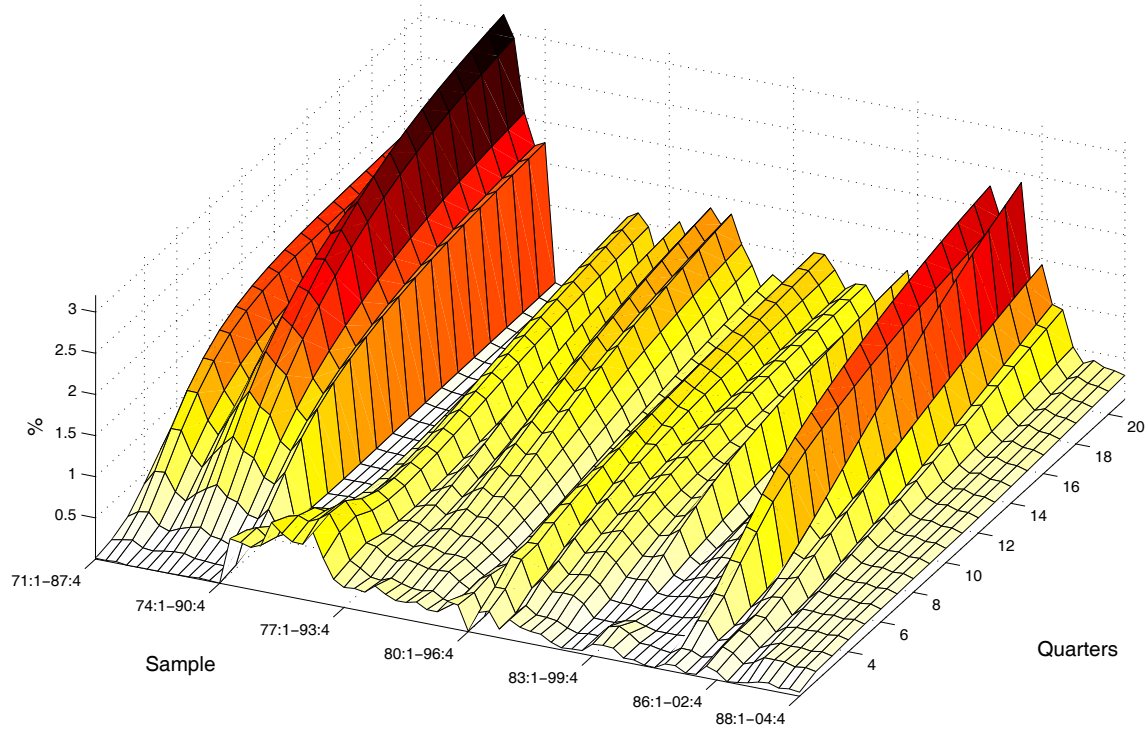

Figure 12b: GDP variance due to government spending shocks

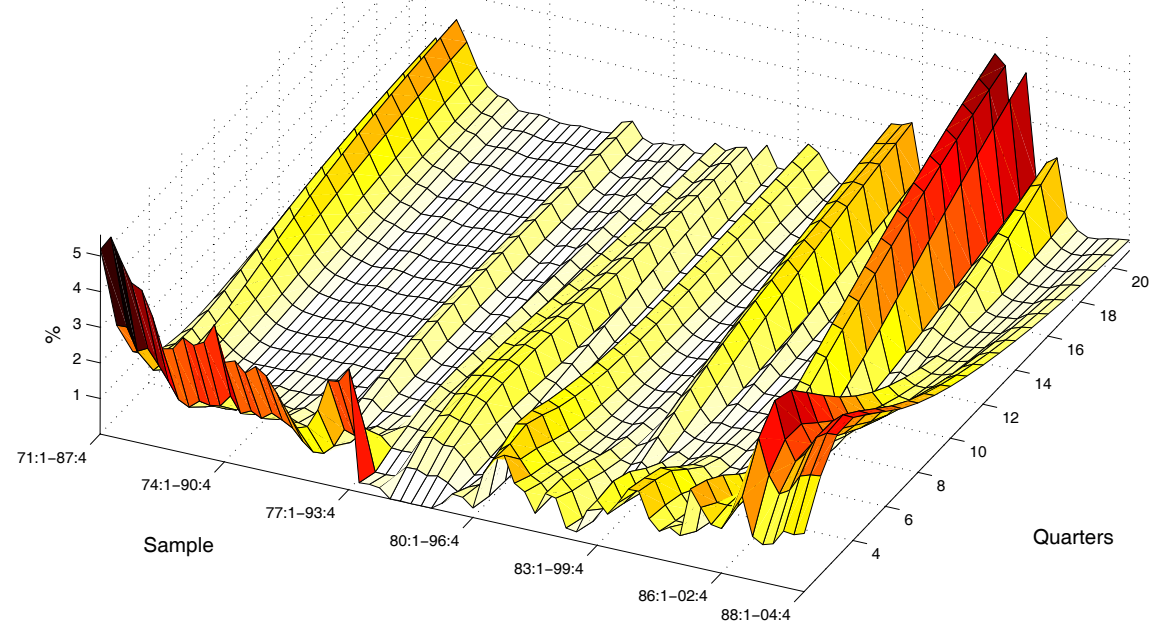

Figure 12: United States. Forecast error variance decomposition. Percentage of GDP variance explained by tax shocks (Figure 11a) and government spending shocks (Figure 11b) over different horizons and data samples. 
Figure 13a: German tax shocks
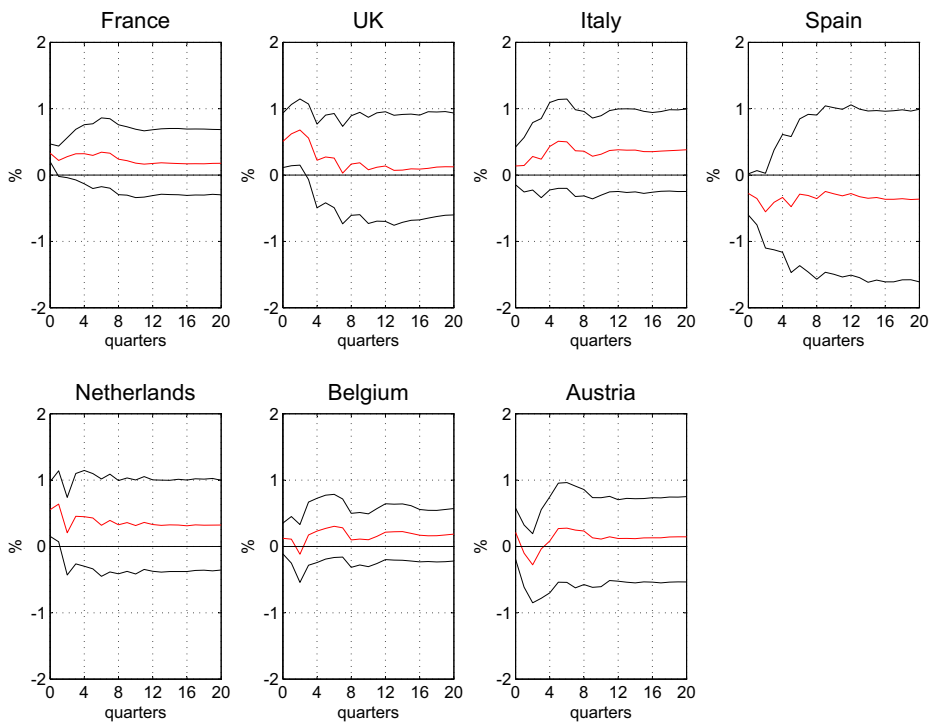

Figure 13b: German government spending shocks
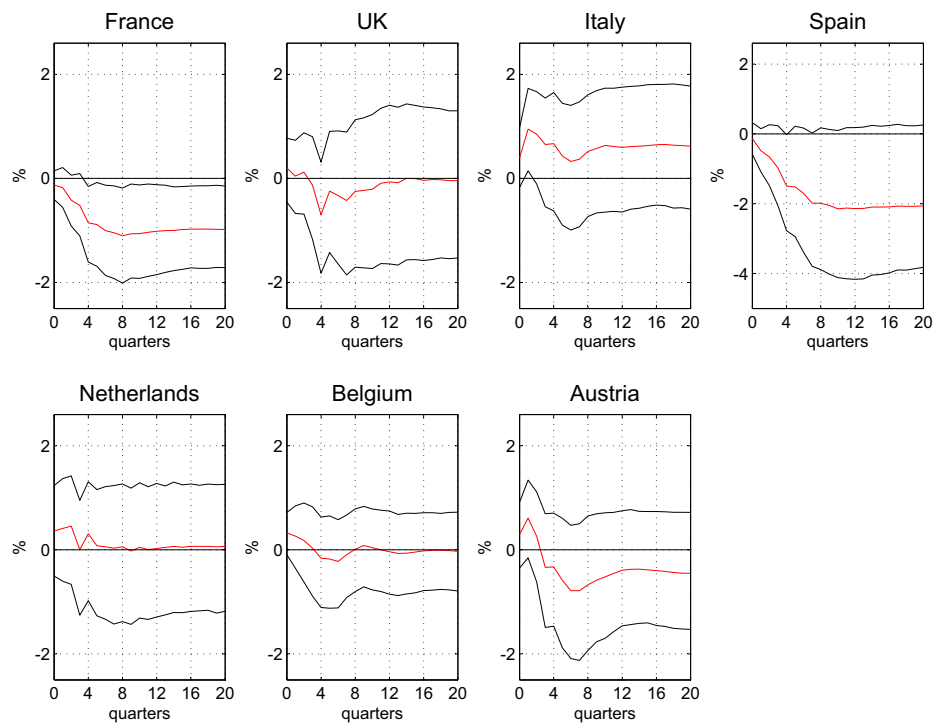

Figure 13: Effects of a German tax shock (Figure 13a) and a German government spending shock (Figure 13b) equal to one percent of German GDP on GDPs of seven European Union countries. Red lines: baseline impulse responses. Black lines: 90\% confidence intervals based on 1000 bootstrap replications. 

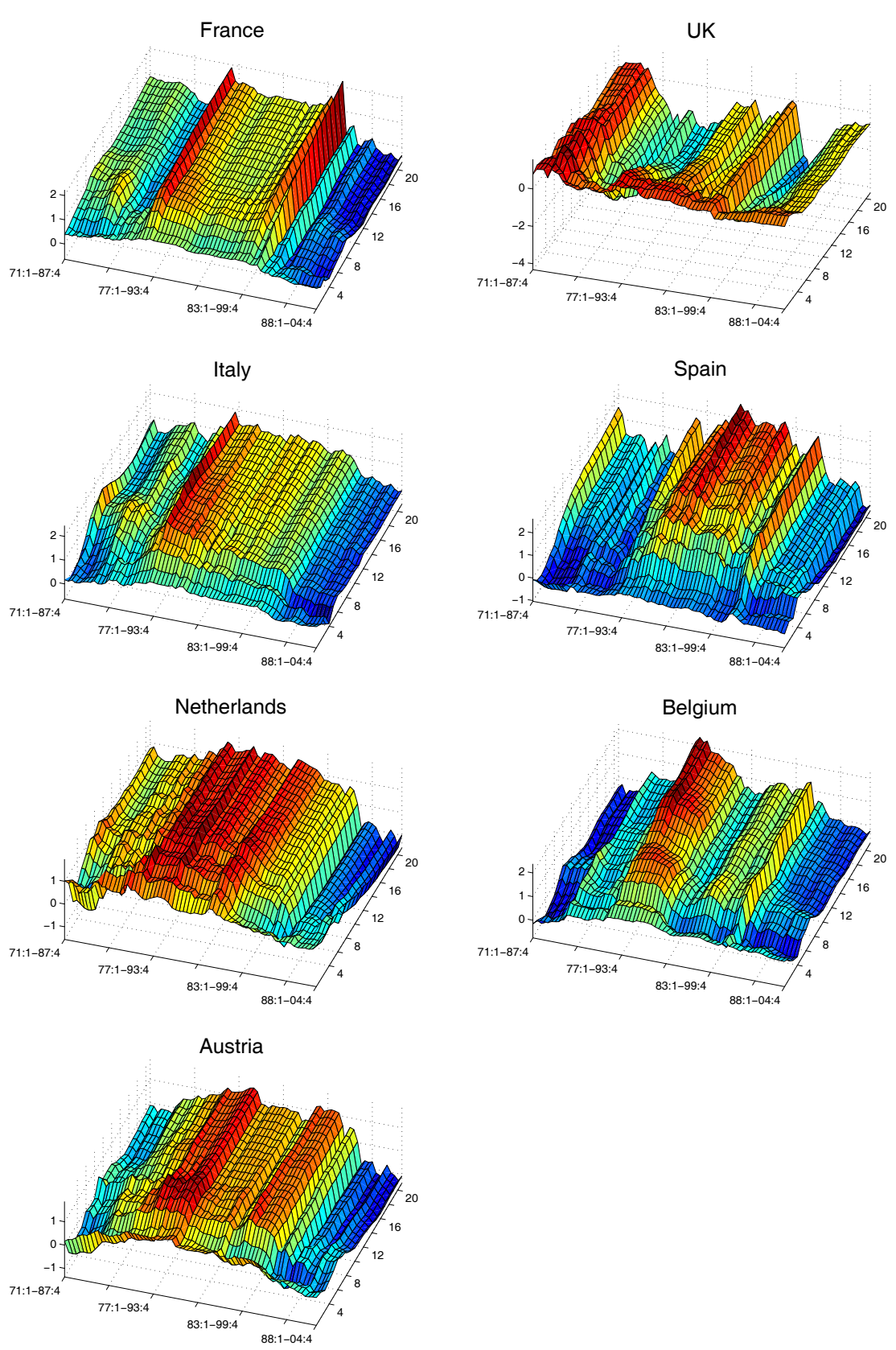

Figure 14: Cross-border GDP multipliers over recursive samples of 17 years. Percentage responses of domestic GDP (seven largest EU countries) to a German negative tax shock equal to one percent of German GDP. 


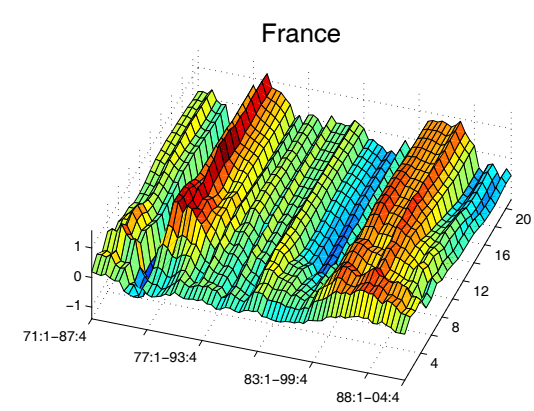

Italy

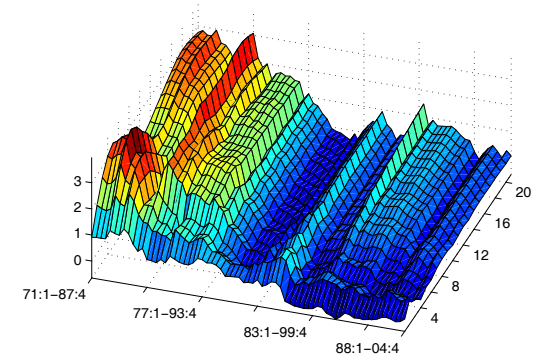

Netherlands

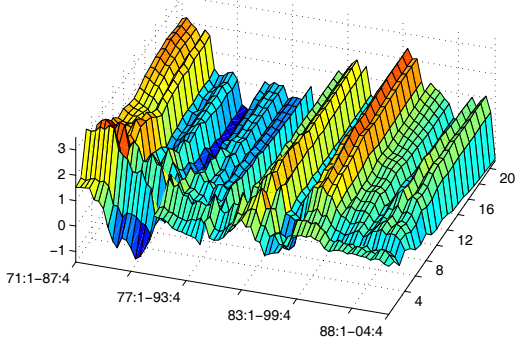

Austria

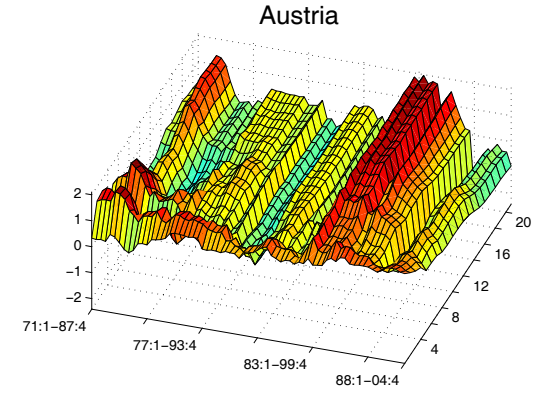

UK

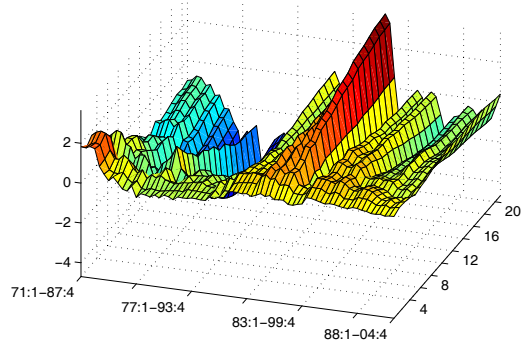

Spain

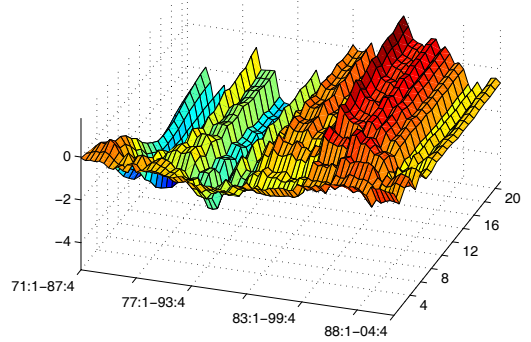

Belgium

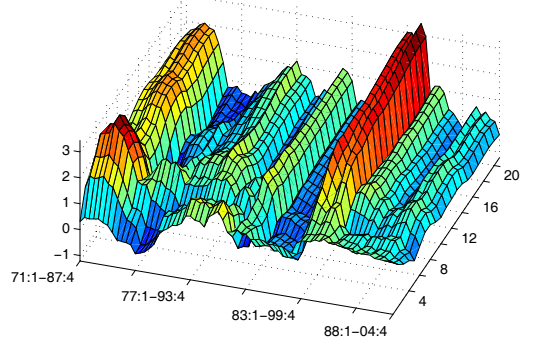

Figure 15: Cross-border GDP multipliers over recursive samples of 17 years. Percentage responses of domestic GDP (seven largest EU countries) to a German negative tax shock equal to one percent of German GDP. 

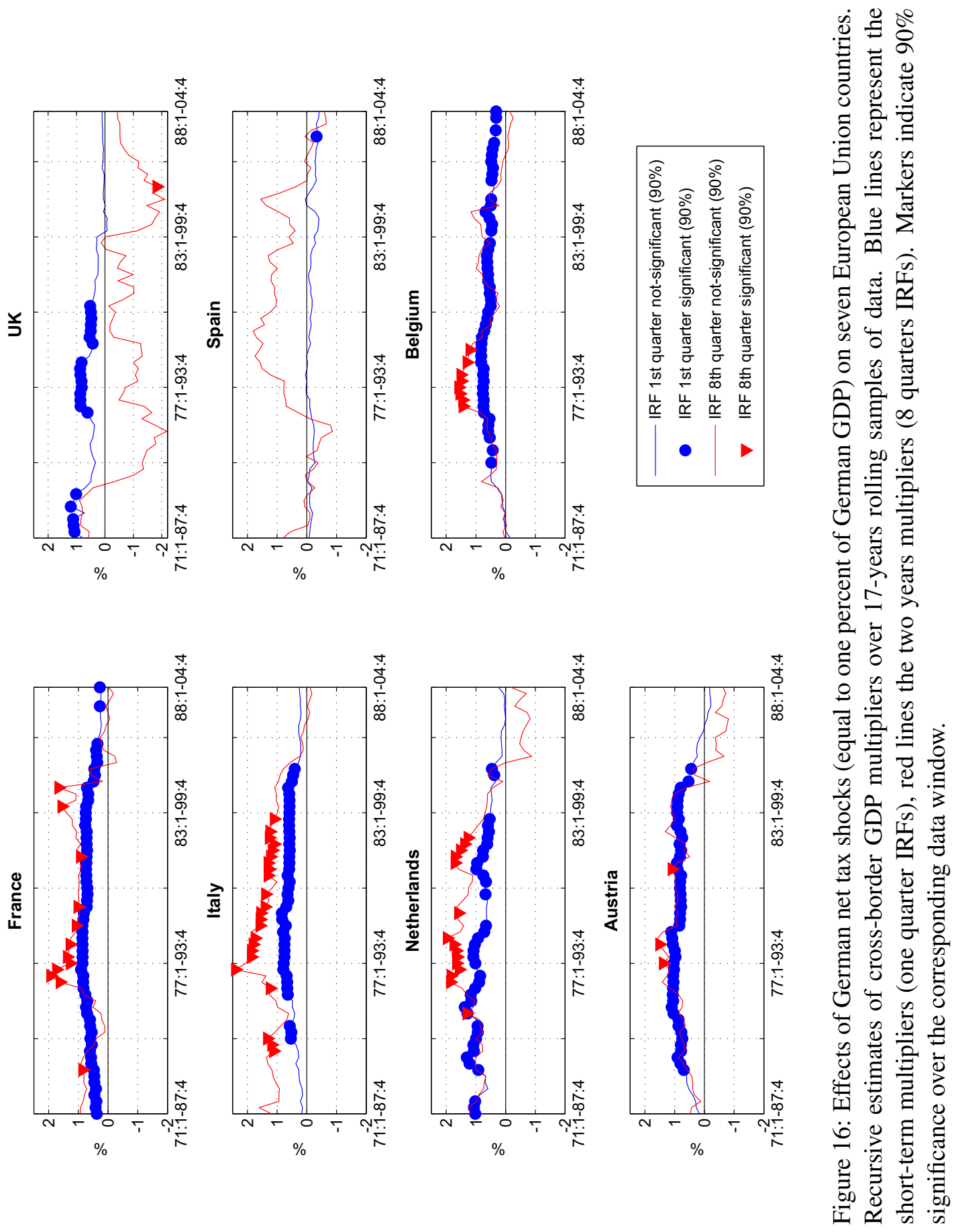

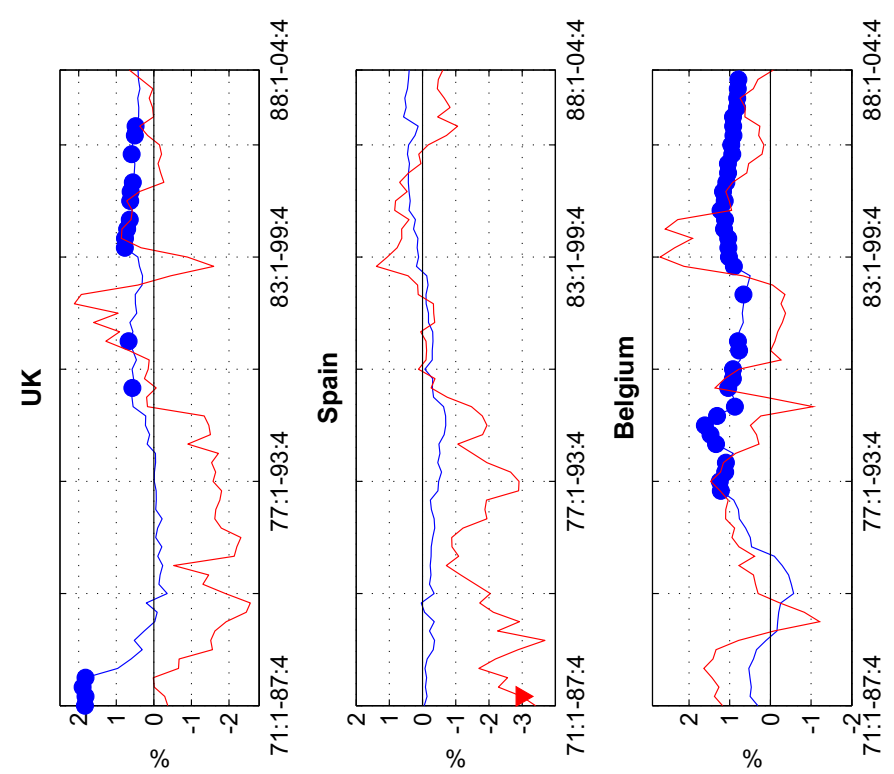

ॠ్

空焉

एँ

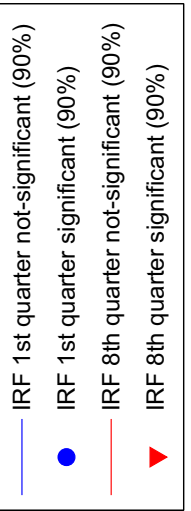

荥苛

ธี

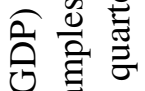

放 $\infty$

छี

ঠั

渮

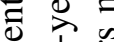

过

¿

¿ 0

월

흘 氞

可芯

㐘 巳
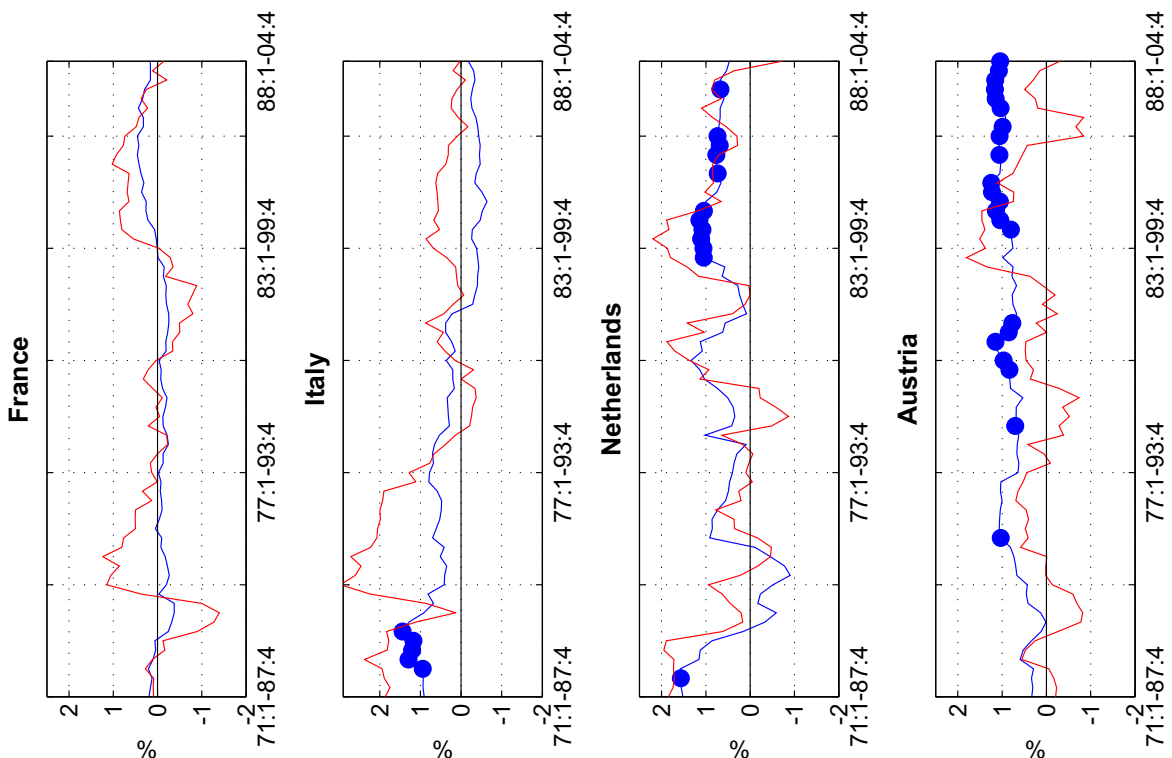

के 0 की

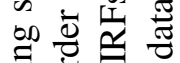

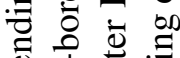

¿

क क 仓

可

छ 0 อ

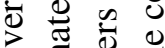

잌.

菏氙

ปี

ঠั

पे छ

曲壳

过 $\dot{\infty} \frac{0}{n}$

딬ㅇㅇㅇ

긍

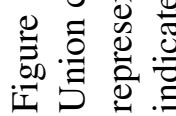



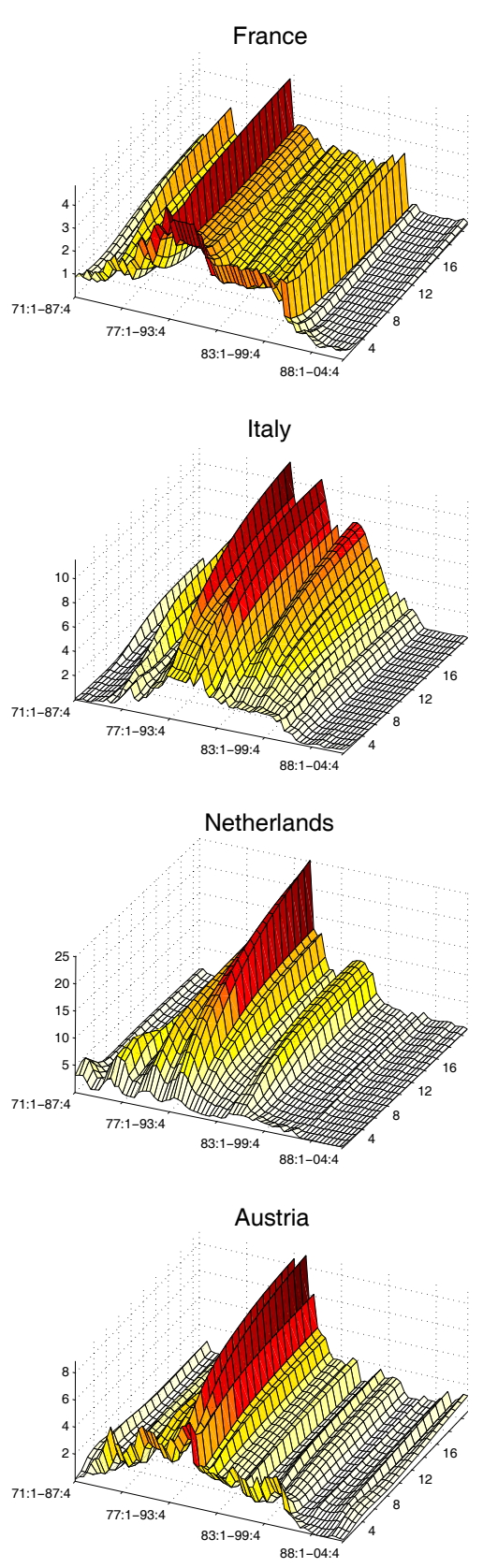

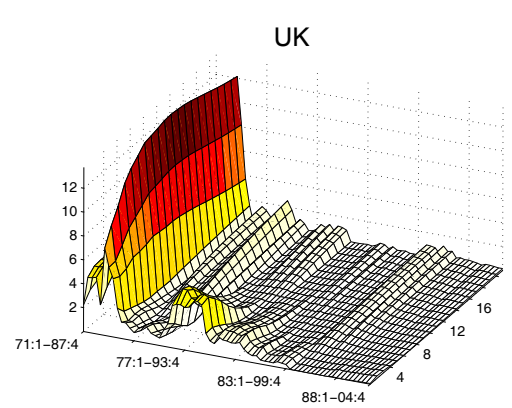

Spain

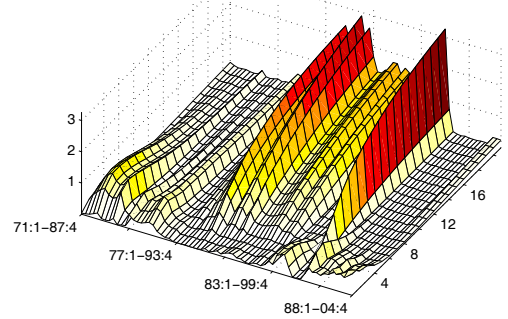

Belgium

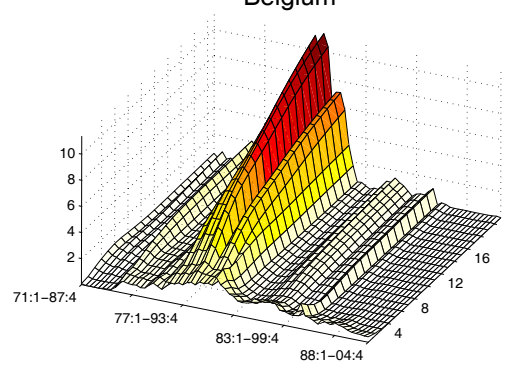

Figure 18: Seven European Union countries. GDP forecast error variance decomposition. Percentage of GDP variance explained by German net tax shocks shocks (equal to one percent of German GDP) over different horizons and data samples. 

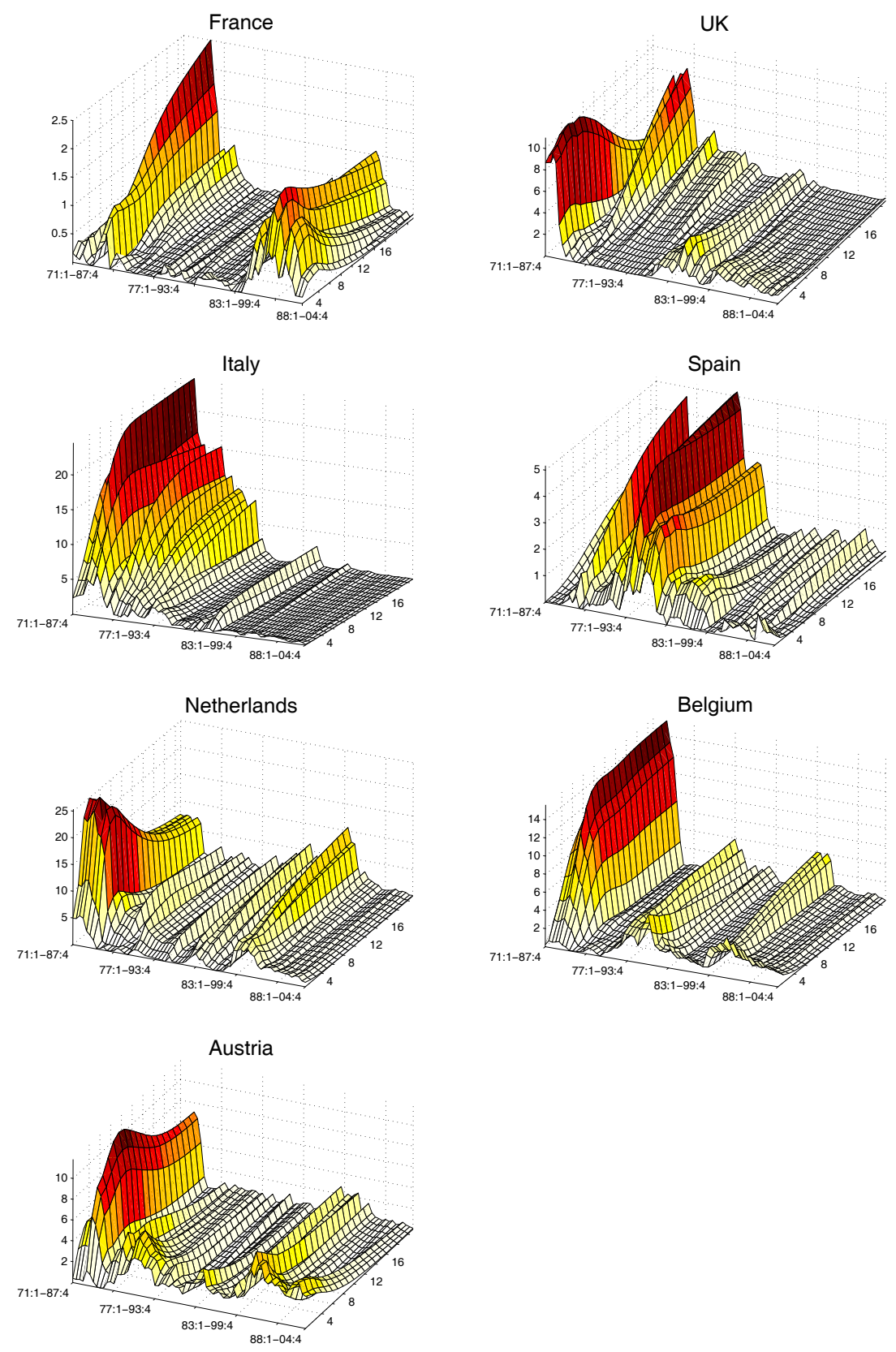

Figure 19: Seven European Union countries. GDP forecast error variance decomposition. Percentage of GDP variance explained by German government spending shocks (equal to one percent of German GDP) over different horizons and data samples. 
Figure 20a: Germany.

GDP impulse response functions
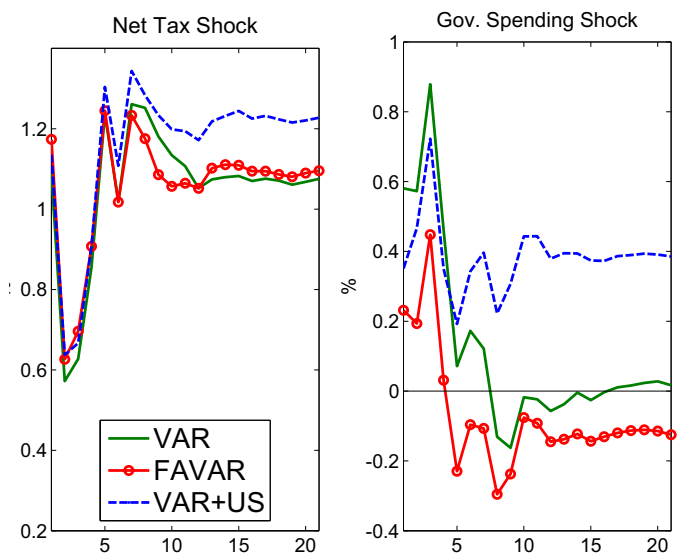

GDP variance decomposition

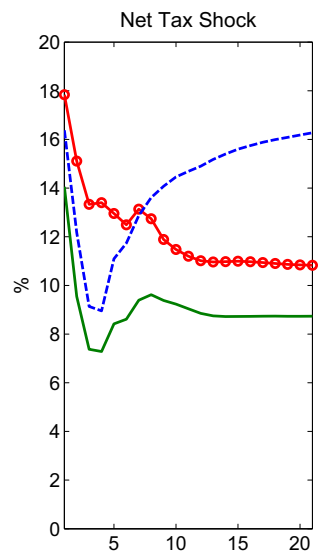

Figure 20b: United Kingdom.

GDP Impulse response functions
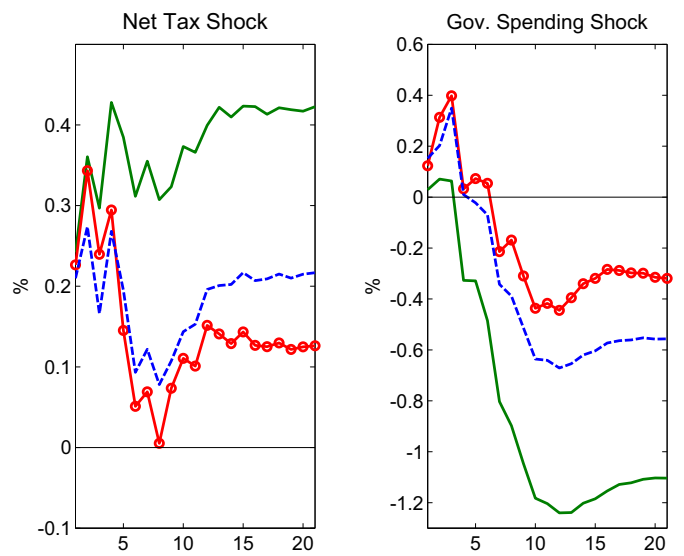

GDP variance decomposition

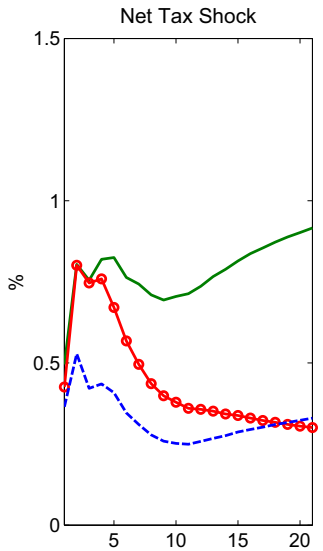

Figure 20: Comparison between the baseline fiscal FAVAR in model (2), VAR including the US GDP and Federal Fund Rate as control variables (VAR+US) and VARs without control factors. For the three models, GDP impulse responses and GDP forecast error variances due to domestic net tax and government spending shocks are displayed. Sample: 1971:1 - 2004:4. 


\section{List of Working Papers Released by CEPII}

No

2006-23 Market Access Impact on Individual Wage: Evidence from China

2006-22 FDI in Chinese Cities: Spillovers and Impact on Growth

2006-21 Are Financial Distortions an Impediment to Economic Growth? Evidence from China

2006-20 World Consistent Equilibrium Exchange Rates

2006-19 Institutions and Bilateral Asset Holdings

2006-18 Vertical Production Networks: Evidence from France

2006-17 Import Prices, Variety and the Extensive Margin of Trade

2006-16 The Long Term Growth Prospects of the World Economy: Horizon 2050

2006-15 Economic Integration in Asia: Bilateral Free Trade Agreements Versus Asian Single Market

2006-14 Foreign Direct Investment in China: Reward or Remedy?

2006-13 Short-Term Fiscal Spillovers in a Monetary Union

2006-12 Can Firms' Location Decisions Counteract the Balassa-Samuelson Effect?

2006-11 Who's Afraid of Tax Competition? Harmless Tax Competition from the New European Member States

2006-10 A Quantitative Assessment of the Outcome of the Doha Development Agenda

2006-09 Disparities in Pension Financing in Europe: Economic and Financial Consequences

2006-08 Base de données CHELEM-BAL du CEPII

2006-07 Deindustrialisation and the Fear of Relocations in the Industry
Authors

Laura Hering

Sandra Poncet

Nicole Madariaga

Sandra Poncet

Alessandra Guariglia Sandra Poncet

A. Bénassy-Quéré,

A. Lahrèche-Révil \& V. Mignon

V. Salins

\& A. Bénassy-Quéré

M. Fouquin,

L. Nayman

\& L. Wagner

G. Gaulier

\& I. Méjean

S. Poncet

M. H. Bchir \& M. Fouquin

O. Havrylchyk $\&$ S. Poncet

A. Bénassy-Quéré

I. Méjean

A. Lahrèche-Révil

Y. Decreux

\& L. Fontagné

J. Château \& X. Chojnicki

H. Boumellassa \& D. Ünal-Kesenci

H. Boulhol \& L. Fontagné 
2006-06 A Dynamic Perspective for the Reform of the Stability

C. Deubner and Gowth Pact

2006-05 China's Emergence and the Reorganisation of Trade Flows in Asia

G. Gaulier, F. Lemoine \& D. Ünal-Kesenci

2006-04 Who Pays China's Bank Restructuring Bill?

G. Ma

2006-03 Structural Determinants of the Exchange-Rate PassThrough

G. Gaulier, A. Lahrèche-Révil \& I. Méjean

2006-02 Exchange-Rate Pass-Through at the Product Level

2006-01 Je t'aime, moi non plus : Bilateral Opinions and International Trade

G. Gaulier, A. Lahrèche-Révil \& I. Méjean

A.C. Disdier \& T. Mayer

2005-23 World Trade Competitiveness: A Disaggregated View by Shift-Share Analysis

A. Cheptea, G. Gaulier \& S. Zignago

2005-22 Chômage et réformes du marché du travail au Japon

E. Dourille-Feer

2005-21 Profitability of Foreign and Domestic Banks in Central and Eastern Europe: Does the Mode of Entry Matter?

2005-20 ECB Governance in an Enlarged Eurozone

A. Bénassy-Quéré \& E. Turkisch

2005-19 What Are EU Trade Preferences Worth for SubSaharan Africa and Other Developing Countries?

2005-18 Binding Overhang and Tariff-Cutting Formulas

2005-17 International Trade and Income Distribution: Reconsidering the Evidence

O. Havrylchyk \& E. Jurzyk

F. Candau \& S. Jean

M.H. Bchir, S. Jean \&

D. Laborde

I. Bensidoun, S. Jean \&

A. Sztulman

2005-16 China and the Relationship between the Oil Price and the Dollar

A. Bénassy-Quéré, V. Mignon \& A. Penot

2005-15 Consequences of Alternative Formulas for Agricultural Tariff Cuts

2005-14 Is Erosion of Tariff Preferences a Serious Concern?

2005-13 The Consequences of Agricultural Trade Liberalization for Developing Countries: Distinguishing Between Genuine Benefits and False Hopes

S. Jean, D. Laborde \& W. Martin

A. Bouët, L. Fontagné $\&$ S. Jean

J.C. Bureau, S. Jean A. Matthews 
2005-12 From Bound Duties to Actual Protection: Industrial Liberalisation in the Doha Round

2005-11 Impact de l'ouverture financière sur les inégalités internes dans les pays émergents

2005-10 Disentangling Horizontal and Vertical Intra-Industry Trade

2005-09 China's Integration in East Asia: Production Sharing, FDI \& High-Tech Trade

2005-08 Tax Competition and Public Input

2005-07 Trade Liberalisation, Growth and Poverty in Senegal: A Dynamic Microsimulation CGE Model Analysis

2005-06 Migration, Trade and Wages

2005-05 Institutional Determinants of Foreign Investment

2005-04 L'économie indienne : changements structurels et perspectives à long terme

2005-03 Programme de travail du CEPII pour 2005

2005-02 Market Access in Global and Regional Trade

2005-01 Real Equilibrium Exchange Rate in China

2004-22 A Consistent, ad-valorem Equivalent Measure of Applied Protection Across the World: The MAcMapHS6 Database

2004-21 IMF in Theory: Sovereign Debts, Judicialisation and Multilateralism

2004-20 The Impact of Multilateral Liberalisation on European Regions: a CGE Assessment

2004-19 La compétitivité de l'agriculture et des industries agroalimentaires dans le Mercosur et l'Union européenne dans une perspective de libéralisation commerciale

2004-18 Multilateral Agricultural Trade Liberalization: The Contrasting Fortunes of Developing Countries in the
M.H. Bchir,

L. Fontagné \& S. Jean

A. Bénassy-Quéré \& V. Salins

L. Fontagné, M. Freudenberg \&

G. Gaulier

G. Gaulier, F. Lemoine D. Ünal-Kesenci

A. Bénassy-Quéré, N. Gobalraja \&

A. Trannoy

N. Annabi, F. Cissé,

J. Cockburn \&

B. Decaluwé

A. Hijzen \& P. Wright

A. Bénassy-Quéré, M. Coupet \& T. Mayer

S. Chauvin \& F. Lemoine

T. Mayer \& S. Zignago

V. Coudert \&

C. Couharde

A. Bouët, Y. Decreux,

L. Fontagné, S. Jean \& D. Laborde

J. Sgard

S. Jean \& D. Laborde

N. Mulder, A. Vialou, B. David,

M. Rodriguez \& M. Castilho

A. Bouët, J.C. Bureau, Y. Decreux \& S. Jean 
Doha Round

2004-17 UK in or UK out? A Common Cycle Analysis

J. Garnier between the UK and the Euro Zone

2004-16 Regionalism and the Regionalisation of International Trade

G. Gaulier, S. Jean \&

D. Ünal-Kesenci

2004-15 The Stock-Flow Approach to the Real Exchange Rate of CEE Transition Economies

B. Egert,

A. Lahrècche-Révil \&

K. Lommatzsch

2004-14 Vieillissement démographique, épargne et retraite : une analyse à l'aide d'un modèle d'équilibre général à agents hétérogènes

2004-13 Burden Sharing and Exchange-Rate Misalignments within the Group of Twenty

C. Bac \& J. Chateau

A. Bénassy-Quéré,

P. Duran-Vigneron,

A. Lahrèche-Révil \&

V. Mignon

2004-12 Regulation and Wage Premia

S. Jean \& G. Nicoletti

2004-11 The Efficiency of Fiscal Policies: a Survey of the

S. Capet Literature

2004-10 La réforme du marché du travail en Allemagne : les enseignements d'une maquette

S. Capet

2004-09 Typologie et équivalence des systèmes de retraites

2004-08 South - South Trade: Geography Matters

P. Villa

S. Coulibaly \&

L. Fontagné

2004-07 Current Accounts Dynamics in New EU Members: Sustainability and Policy Issues

P. Zanghieri

2004-06 Incertitude radicale et choix du modèle

P. Villa

2004-05 Does Exchange Rate Regime Explain Differences in Economic Results for Asian Countries?

V. Coudert \&

M. Dubert

2004-04 Trade in the Triad: How Easy is the Access to Large Markets?

L. Fontagné, T. Mayer \& S. Zignago

2004-03 Programme de travail du CEPII pour 2004

2004-02 Technology Differences, Institutions and Economic Growth: a Conditional Conditional Convergence

H. Boulhol

2004-01 Croissance et régimes d'investissement

P. Villa

2003-22 A New Look at the Feldstein-Horioka Puzzle using a Integrated Panel

A. Banerjee

P. Zanghieri 
2003-21 Trade Linkages and Exchange Rates in Asia :The Role of China

2003-20 Economic Implications of Trade Liberalization Under the Doha Round

2003-19 Methodological Tools for SIA - Report of the CEPII Worshop held on 7-8 November 2002 in Brussels

2003-18 Order Flows, Delta Hedging and Exchange Rate Dynamics

2003-17 Tax Competition and Foreign Direct Investment

2003-16 Commerce et transfert de technologies : les cas comparés de la Turquie, de l'Inde et de la Chine

2003-15 The Empirics of Agglomeration and Trade

2003-14 Notional Defined Contribution: A Comparison of the French and German Point Systems

2003-13 How Different is Eastern Europe? Structure and Determinants of Location Choices by French Firms in Eastern and Western Europe

2003-12 Market Access Liberalisation in the Doha Round: Scenarios and Assessment

2003-11 On the Adequacy of Monetary Arrangements in SubSaharian Africa

2003-10 The Impact of EU Enlargement on Member States: a CGE Approach

2003-09 India in the World Economy: Traditional Specialisations and Technology Niches

2003-08 Imitation Amongst Exchange-Rate Forecasters: Evidence from Survey Data

2003-07 Le Currency Board à travers l'expérience de l'Argentine

2003-06 Trade and Convergence: Revisiting Ben-Davil

2003-05 Estimating the Fundamental Equilibrium Exchange Rate of Central and Eastern European Countries the EMU Enlargement Perspective
A. Bénassy-Quéré \& A. Lahrèche-Révil

J. Francois, H. van Meijl \& F. van Tongeren

B. Rzepkowski

A. Bénassy-Quéré, L. Fontagné \&

A. Lahrèche-Révil

F. Lemoine \&

D. Ünal-Kesenci

K. Head \& T. Mayer

F. Legros

A.C. Disdier \& T. Mayer

L. Fontagné, J.L. Guérin \& S. Jean

A. Bénassy-Quéré \& M. Coupet

H. Bchir, L. Fontagné \& P. Zanghieri

S. Chauvin \& F. Lemoine

M. Beine, A. Bénassy-Quéré \& H. Colas

S. Chauvin \& P. Villa

G. Gaulier

B. Egert \&

A. Lahrèche-Révil 
2003-04 Skills, Technology and Growth is ICT the Key to Success?

2003-03 L'investissement en TIC aux Etats-Unis et dans quelques pays européens

2003-02 Can Business and Social Networks Explain the Border Effect Puzzle?
J. Melka, L. Nayman,

S. Zignago \& N. Mulder

G. Cette \& P.A. Noual

P.P. Combes, M. Lafourcade \& T. Mayer 


\section{CEPII \\ DOCUMENTS DE TRAVAIL / WORKING PAPERS}

Si vous souhaitez recevoir des Documents de travail, merci de remplir le coupon-réponse ci-joint et de le retourner à :

Should you wish to receive copies of the CEPII's Working papers, just fill the reply card and return it to:

Sylvie HURION - Publications

CEPII - 9, rue Georges-Pitard - 75740 Paris - Fax : (33) 1.53.68.55.04

sylvie.hurion@cepii.fr

M./Mme / Mr./Mrs

Nom-Prénom / Name-First name.

Titre / Title.

Service / Department

Organisme / Organisation.

Adresse / Address.

Ville \& CP / City \& post code

Pays / Country Tél.

Your e-mail.

Désire recevoir les Document de travail du CEPII $n^{\circ}$ :

Wish to receive the CEPII's Working Papers No:

Souhaite être placé sur la liste de diffusion permanente (pour les bibliothèques)

Wish to be placed on the standing mailing list (for Libraries). 